\title{
Exploring the potential effects of marine protected areas on the ecosystem structure of the Gulf of Gabes using the Ecospace model
}

\author{
Khaled AbDou $^{1,2, a}$, Ghassen Halouani ${ }^{1,2}$, Tarek HATtAB ${ }^{3}$, Mohamed Salah Romdhane ${ }^{1}$, \\ Frida Ben Rais LASRAM ${ }^{1}$ and François Le LOC' ${ }^{2}$ \\ 1 UR 03AGRO1 Ecosystèmes et Ressources Aquatiques, Institut National Agronomique de Tunisie, 43 Avenue Charles Nicolle, \\ 1082 Tunis, Tunisia \\ 2 UMR 6539 Laboratoire des Sciences de l'Environnement Marin (CNRS/UBO/IRD/Ifremer), Institut Universitaire Européen \\ de la Mer, Technopôle Brest-Iroise, Rue Dumont d'Urville, 29280 Plouzané, France \\ 3 Unité de Recherche Écologie et Dynamique des Systèmes Anthropisés (EDYSAN FRE 3498 CNRS-UPJV), Université de Picardie \\ Jules Verne, Rue des Louvels, 80000 Amiens, France
}

Received 27 November 2015; Accepted 13 April 2016

\begin{abstract}
The Gulf of Gabes is considered as one of the most productive areas of the southern Mediterranean Sea and it plays an important role in Tunisian economy. It is known to be an archetypal ecosystem in which the effects of fisheries are the most pronounced. Based on the stock assessment outcomes, it is as a highly exploited ecosystem. Thereupon, it becomes necessary to establish adequate measures to facilitate the recovery of the marine resources. The most important sets of management measures regard the establishment of Marine Protected Areas (MPAs). However, these management plans should be assessed beforehand to make sure of the relevance of the measure and its impact on marine resources. Modeling may significantly enhance our understanding of the likely impacts of fisheries management plans on groups that are very difficult to study and this approach gives insights at larger spatial scales. We used Ecospace to investigate the potential impacts of several spatial management plans on the ecosystem structure of the Gulf of Gabes. The Ecospace model is based on the existing Ecopath model elaborated by Hattab (2013). The simulation were carried over a 15-year period. The outcomes of the simulations, suggest that the implementation of MPAs in the Gulf of Gabes could be simultaneously beneficial for the ecosystem and fishing activities. However, the benefits are related to the characteristics of the MPA. The spatial simulations highlight that the location is crucial to the success of the MPA. Additionally, an increase in the size of a MPA can result in an increase in the spillover effect and, consequently, in catches in the neighborhood without harming ecosystem integrity. The configuration of the implemented MPA is of capital importance, a set of many small MPAs is more beneficial than fewer and larger MPAs, especially in terms of catches.
\end{abstract}

Keywords: Ecospace / Gulf of Gabes / fisheries management / marine protected areas (MPA)

\section{Introduction}

The demand for seafood has increased rapidly since the Industrial Revolution with the increase in human population size, resulting in substantial expansion of fisheries (Jackson et al. 2001; Halpern et al. 2008). Fishing activities not only expanded in terms of number of fishing units but also in terms of fishing grounds, including waters of all depths and habitat types (Pauly et al. 2002). The increased provision of seafood entails risks of ecological deterioration of marine ecosystems, as well as direct and indirect impacts of fisheries on the ecosystem (Jennings and Kaiser 1998; Kaiser and de Groot 2000). In

a Corresponding author: abdou.khaledfb@hotmail.fr addition to depleting target stocks and changing species abundance (Lotze et al. 2006), fishing may modify food webs and destroy habitats (Pauly et al. 2002; Worm et al. 2006). Furthermore, Mediterranean marine ecosystems are subject to several other anthropogenic pressures, such as habitat degradation, pollution, climate change and invasion by exotic species (Coll et al. 2010).

The focus of traditional fisheries management has been on single species, which does not account for the temporal and biological complexity and dynamics of ecosystems. Therefore, a shift towards integrated and more comprehensive approaches to management has become a necessity to manage the increase in resource use and to maintain the structure and functioning 
of ecosystems (Browman and Stergiou 2004). This shift is currently underway via ecosystem-based management approaches and the use of marine spatial planning tools that aim to exploit marine resources in a sustainable and profitable manner while maintaining a balanced ecosystem (Cochrane and De Young 2008).

The designation of marine protected areas (MPA) is a widely advocated approach to marine resource management (Colléter et al. 2014; Gell and Roberts 2003; Lubchenco et al. 2003), and protected areas have been implemented worldwide as part of the ecosystem-based approach (Gaines et al. 2010; Pauly et al. 2002). MPAs have proven to be effective for the protection of marine biodiversity, minimizing the negative impact of human activities (Gaines et al. 2010; Rossetto et al. 2015). In addition to the benefits inside an MPA, which allow the abundance and biodiversity of some fish populations to increase, an MPA may be beneficial for the surrounding fishing zones through the emigration of fishes and the export of pelagic eggs and larvae, which can sustain recruitment in those adjacent areas (Gell and Roberts 2003; Gerber et al. 2003; Harrison et al. 2012). The increase of catches around an MPA may be explained by a "spillover" effect, characterized by the export of fish and reproductive propagules to adjacent unprotected areas after increasing their densities and sizes inside the MPA (Gell and Roberts 2003; Ward et al. 2001).

MPAs can also have unexpected negative effects. For example, when an MPA favors the increase of predators, a decrease in prey populations might occur. This phenomenon has been identified in several ecosystems (e.g., Malindi Kisite and Watamu Marine National Parks in Kenya; Leigh Marine Reserve in New Zealand; and Brackett's Landing Conservation Area in the USA; Pinnegar et al. 2004). Moreover, the establishment of an MPA could result in a decrease in catches, especially in the short term (Colléter et al. 2014). In some cases an MPA is considered a biological success but a social failure (e.g., Bunaken National Park in Indonesia; San Salvador Island, Twin Rocks, Balicasag Island, Glan Padidu Marine Sanctuary and Kapatan Marine Reserve in the Philippines) (Christie 2004; Razon et al. 2012). Therefore, it is important to evaluate the potential effects of an MPA beforehand. Its expected effectiveness is directly related to location, size and configuration (Browman and Stergiou 2004; Halpern 2003; Hilborn et al. 2004).

Ecosystem models can be used to assess potential ecosystem responses to multiple management scenarios (Christensen et al. 2008; Coll and Libralato 2012). Among the available ecosystem models, Ecopath with Ecosim (EwE, Christensen and Walters 2004) is one of the most widely used. The Ecospace module (Walters et al. 1999) of EwE allows for assessment of the effectiveness of multiple potential marine protected areas as it considers the dispersal rates of species as well as the spatial distribution of fishing efforts. The Ecospace framework has been used in several studies (Fouzai et al. 2012; Romagnoni et al. 2015). To the best of our knowledge, this study represents the first attempt to use this method to assess fishery management alternatives in the Southern Mediterranean Sea.

The Gulf of Gabes is a major fishing ground off Tunisia of great economic and ecological importance, and is considered to be one of the most productive areas in the Mediterranean Sea in terms of catches (Papaconstantinou and Farrugio 2000). However, since the 1980s, there has been an expansion of fisheries and, as a result, several stocks such as hake have been reported to be highly or over-exploited (Fiorentino et al. 2008). Based on Fisheries and Aquaculture Department (DGPA) statistics, a continual increase in the number of trawlers occurred from early 1980 until 1991 (285 trawlers) followed by a decline to 229 trawlers in 1997. Since 1997, the number of trawlers has fluctuated around 250. The increase in the fleet size can be explained by the richness of benthic resources (shrimps, mullets, soles, etc.) and the presence of soft bottom habitats facilitating access to these resources (Missaoui et al. 2000).

Therefore, a mass-balance model has been developed to further understand the functioning of the ecosystem and to represent the average situation of the Gulf (Hattab et al. 2013a). Based on this model, we developed an Ecospace model to assess potential ecosystem feedbacks for several spatial management scenarios (marine protected areas).

\section{Materials and methods}

\subsection{Study area}

The Gulf of Gabes is located in the southern Mediterranean Sea on the eastern coast of Tunisia, and covers approximately $35900 \mathrm{~km}^{2}$ (Fig. 1). An important feature of this region is the unique geomorphological and hydrodynamic pattern. The basin is very shallow (a depth of $200 \mathrm{~m}$ is only reached at a distance of $400 \mathrm{~km}$ from the coastline), which increases the sensitivity to atmospheric changes (Natale et al. 2006). The Gulf is also known to have the highest tidal amplitude in the Mediterranean, reaching $1.8 \mathrm{~m}$ in height (Sammari et al. 2006).

The Gulf of Gabes is home to one of the world's largest seagrass beds of Posidonia oceanica (Batisse and Jeudy de Grissac 1998), offering a nursery ground for many marine species (Hattour 1991). The seafloor is primarily soft bottom (Brahim et al. 2003), resulting in the prevalence of bottom trawling activities in these waters.

\subsection{Ecopath with Ecosim model of the Gulf of Gabes}

Ecopath, in essence, represents a static snapshot of interactions between functional groups in an ecosystem (Christensen and Walters 2004). Ecopath is a mass-balance model based on the master equation (1):

$$
P_{i}=Y_{i}+B_{i} M 2_{i}+E_{i}+B A_{i}+P_{i}\left(1-E E_{i}\right)
$$

where $P_{i}$ is the production of functional group $i, Y_{i}$ the fishery catch rate, $B_{i}$ the biomass of group $i, M 2_{i}$ represents predation mortality, $E_{i}$ the net migration rate (emigration - immigration), $B A_{i}$ the biomass accumulation rate, $P_{i}\left(1-E E_{i}\right)$ the mortality from other sources and $E E_{i}$ represents ecotrophic efficiency.

Equation (1) describes how to split the production of each group into components. Ecopath further splits the internal energy flow for each group according to the following 


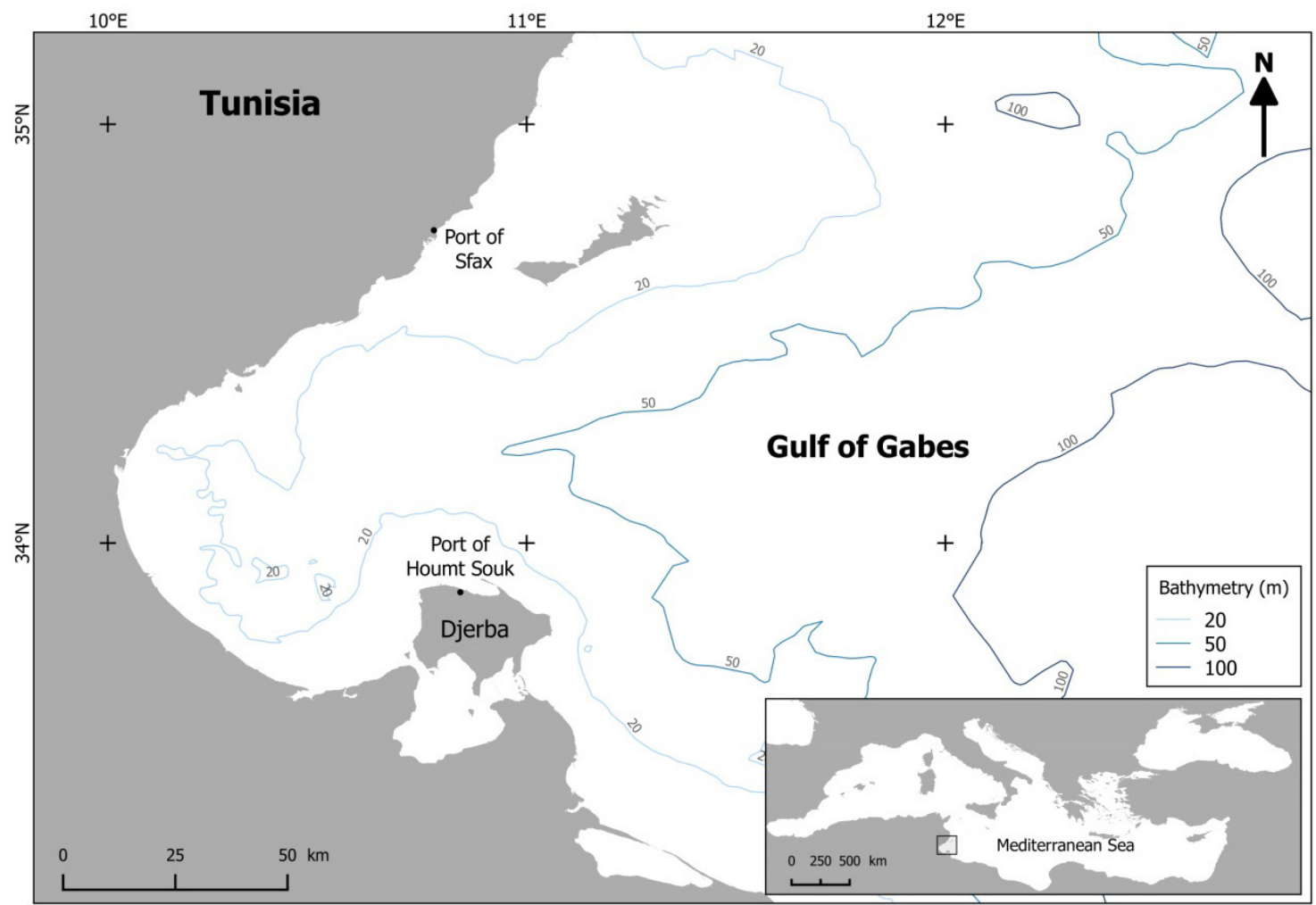

Fig. 1. Geographic location of the study area, the Gulf of Gabes ecosystem.

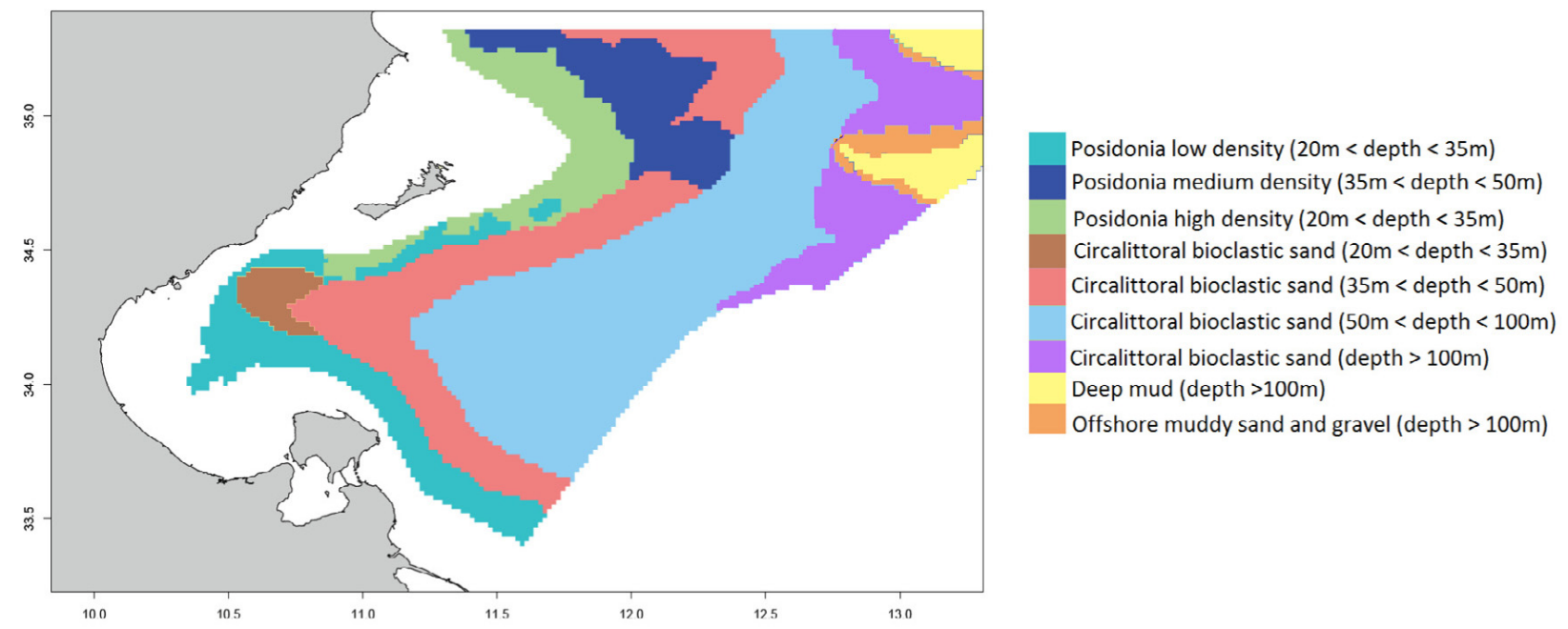

Fig. 2. Spatial extent of the study area and the habitats types included in the Ecospace model.

equation (2):

$$
Q_{i}=P_{i}+R_{i}+Q_{i} G S_{i}
$$

with $R_{i}$ the respiration of group $i, G S_{i}$ the proportion of unassimilated food and $Q_{i}$ the total consumption rate.

Spatial simulations were based on a trophic model for the Gulf of Gabes that had been created using the Ecopath with Ecosim approach, Version 6.2 (www.ecopath.org; Christensen and Walters 2004; Walters et al. 1999). The model was developed to assess ecosystem functioning and characterize foodweb structure during the period 2000-2005. For this model, the area shallower than $20 \mathrm{~m}$ was excluded because of lack of reliable data.

The balanced Ecopath model included 62 species divided into 41 functional groups based on ecological and taxonomic similarities (Hattab et al. 2013a). Fisheries in the Gulf of Gabes are considered to be multigear and multispecies (Jabeur et al. 2000). Therefore, the model encompassed six fishery types - bottom trawling, small seines, tuna purse seines, purse seines using lights (lamparos), coastal motorized fishing and sponge fishing. Landings statistics were obtained from DGPA, 
while discards were taken from the literature (Hattab et al. 2013a). Further details on Ecopath model parameterization can be found in Annex 1 and Hattab et al. (2013a). 2004):

The master equation in Ecosim is (Christensen and Walters

$$
\frac{\mathrm{d} B_{i}}{\mathrm{~d} t}=g_{i} \sum_{j} Q_{j i}-\sum_{j} Q_{j i}+I_{i}-\left(M 0_{i}+F_{i}+e_{i}\right) B_{i}
$$

where $\frac{\mathrm{d} B_{i}}{\mathrm{~d} t}$ represents the growth rate in mass of group $i$ during time interval $\mathrm{d} t, g_{i}$ is the net growth efficiency (production/consumption ratio), $M_{i}$ the non-predation natural mortality rate, $F_{i}$ the fishing mortality rate, $e_{i}$ the emigration rate, and $I_{i}$ the immigration rate. The consumption rates are calculated based on the "foraging arena" concept, where the biomass $B_{i}$ is divided into two compartments: vulnerable and invulnerable (Walters et al. 1997) and the transfer rate $\left(v_{i}\right)$ between those two components determines the type of food web control (topdown, bottom-up or wasp-waist).

The Ecosim approach was used to carry out dynamic simulation using the parameters from the balanced Ecopath model. The Ecosim model was fitted to landings for the period 19952008, time series of fishing effort by fishing gear, and stock assessment estimates of functional group biomass (investigations to collect landings data were conducted by the National Institute of Sciences and Technologies of the Sea). In addition, the primary production in the study area for the period 1997-2007 (data from the SeaWIFS project, http://oceancolor.gsfc.nasa. gov/SeaWiFS) was used for calibration (Halouani et al. 2013). To assess goodness-of-fit and robustness of the fitted model, model outputs were compared to landings time series (Annex 2). Then, several established rest period scenarios (temporal fishing closure) were simulated to analyze the response of the ecosystem (Halouani et al. 2013). Because data concerning vulnerability parameters $\left(v_{i}\right)$ could not be found for the study area, an iterative procedure (Monte Carlo) was used to determine their values, which consisted in modifying the vulnerability parameters until the goodness-of-fit was optimized, consequently improving model agreement with available data.

\subsection{Ecospace model}

Ecospace is the spatially explicit time dynamic module of the Ecopath with Ecosim software (www.ecopath.org; Christensen and Walters 2004; Walters et al. 1999). It integrates the trophic and temporal dynamics of Ecopath and Ecosim across a two-dimensional space.

The first step in implementing an Ecospace model is the definition of spatial grid cells. Each cell represents land or water and is assigned to a specific habitat type (Christensen et al. 2008). Initially, the biomass of functional groups is spread equally and homogeneously across all grid cells. Functional groups move between neighboring grid cells, with movements being controlled by several parameters such as dispersal rate (i.e., the ability of a group to move from one cell to another), foraging behavior (i.e., when functional groups search for their prey) and avoidance of predation (i.e., when functional groups try to avoid being predated) (Walters et al. 1999). The dispersal rate of a group is expressed as distance travelled $(\mathrm{km})$ per year, and it represents the ability of organisms to disperse from a given position through random movements (Christensen et al. 2000). Dispersal rates $\left(V_{i}\right)$ are used to calculate the emigration rate $\left(e_{i}\right)$ for each cell (the rate at which organisms leave the grid cell) based on the following equation: $e_{i}=\frac{V_{i}}{\pi L}$, where $L$ is the cell width (Martell et al. 2005). The immigration rate $I$ in equation (3) consists of the four emigration flows from neighboring cells. These flows are calculated using the following formula (Christensen et al. 2014):

$$
B_{\text {out }, r c i}=\sum_{d=1}^{4} e_{i, d} * B_{r c i}
$$

where $B_{\text {out }, r c i}$ represents the emigration flow (for the grid cell in row $r$ and column $c$ ), $e_{i, d}$ expresses the emigration rate, $d$ is the movement direction, and $B_{r c i}$ is the biomass density of group $i$.

\subsection{Ecospace model parameterization}

The spatial domain of the Ecospace model covered the entire Gulf of Gabes. The baseline map was drawn on approximately 25000 square cells, each covering an area of $3.2 \mathrm{~km}^{2}$. The modeled area extended from the $20-\mathrm{m}$ contour depth to approximately the 200-m isobaths, and included nine habitat types based on depth and bottom type (Hattab et al. 2013b) (Fig. 2). After the habitats were defined, two maps representing depth and relative primary production were related to the baseline map (Christensen et al. 2008). The relative primary production map was drawn based on the average concentration of chlorophyll-a in the Gulf of Gabes by averaging monthly SeaWifs images. Each of the 41 functional groups was assigned to its preferred habitat type, i.e. where the feeding rate was high, based on the available information on the ecology and biology of each species and expert advice (Table 1). Six types of fisheries were included in the Gulf of Gabes model, and each was defined and assigned to the fishing zones where they are permitted to fish according to Tunisian fisheries regulations (Table 2).

The distribution of species across the baseline map is governed by dispersal rates, representing the ability of functional groups to move across the spatial grid of the model. For the Gulf of Gabes model, dispersal rates were established based on data available in the literature (Chen et al. 2009; Fouzai et al. 2012; Martell et al. 2005) or the default values recommended by Christensen et al. (2005).

For baseline dispersal rates we used three values: $300 \mathrm{~km} \mathrm{year}{ }^{-1}$ for pelagic species with high mobility, $30 \mathrm{~km} \mathrm{year}{ }^{-1}$ for demersal species with medium mobility, and $3 \mathrm{~km}_{\text {year }}{ }^{-1}$ for non-dispersing species with low mobility (Christensen et al. 2000). The relative dispersal rate in unsuitable habitats represents the number of times that a functional group would multiply their basic dispersal rate to return to its preferred habitats. We assumed multiplication factors ranging from 1 to 5, depending on the mobility of the species. The relative vulnerability to predation in unsuitable habitats is assumed to be equal to two, implying that species are twice as vulnerable to predation in unsuitable habitats (Christensen et al. 2000). Relative feeding rates in unsuitable habitats represent the fact that species in non-preferred habitats are less likely to 
Table 1. Preferred habitats of functional groups in the Gulf of Gabes Ecospace model. (+) sign indicates the assigned habitats.

\begin{tabular}{|c|c|c|c|c|c|c|c|c|c|}
\hline \multirow{3}{*}{ Functional group } & \multicolumn{8}{|c|}{ Habitat type (depth range) } & \multirow{3}{*}{$\begin{array}{l}\text { Posidonia } \\
\text { low density } \\
(20-35 \mathrm{~m})\end{array}$} \\
\hline & Deep & Offshore muddy & \multicolumn{4}{|c|}{ Circalittoral bioclastic muddy sand } & Posidonia & Posidonia & \\
\hline & $\overline{(<100 \mathrm{~m})}$ & $(<100 \mathrm{~m})$ & $(<100 \mathrm{~m})$ & $(50-100 \mathrm{~m})$ & $(35-50 \mathrm{~m})$ & $(20-35 \mathrm{~m})$ & $(20-35 \mathrm{~m})$ & $(35-50 \mathrm{~m})$ & \\
\hline Phytoplankton & + & + & + & + & + & + & + & + & + \\
\hline Macro-algae & & & & & + & + & + & + & + \\
\hline Posidonia oceanic & & & & & & & + & + & + \\
\hline Micro- and mesozooplankton & + & + & + & + & + & + & + & + & + \\
\hline Macrozooplankton & + & + & + & + & + & + & + & + & + \\
\hline Foraminifera & + & + & + & + & + & + & + & + & + \\
\hline Invertebrate suspension feeders & + & + & + & + & + & + & + & + & + \\
\hline Polychaetes & + & + & + & + & + & + & + & + & + \\
\hline Amphipoda and Isopoda & + & + & + & + & + & + & + & + & + \\
\hline Echinoderms & + & + & + & + & + & + & + & + & + \\
\hline Benthic mollusks & + & + & + & + & + & + & + & + & + \\
\hline Crabs & + & + & + & + & + & + & + & + & + \\
\hline Benthic cephalopods & + & + & + & + & + & + & + & + & + \\
\hline Benthopelagic cephalopods & + & + & + & + & + & + & + & + & + \\
\hline Mantis shrimp & & & & + & + & + & + & + & + \\
\hline Caramote prawn & & & & + & + & + & + & + & + \\
\hline Alien shrimps & & & & + & + & + & + & + & + \\
\hline Deep shrimps & + & + & + & + & & & & & \\
\hline Horse mackerel & + & + & + & + & + & + & + & + & + \\
\hline European pilchard & + & + & + & + & + & + & + & + & + \\
\hline Round sardinella & + & + & + & + & + & + & + & + & + \\
\hline European anchovy & + & + & + & + & + & + & + & + & + \\
\hline Picarel & + & + & + & + & + & + & + & + & + \\
\hline Bogue & + & + & + & + & + & + & + & + & + \\
\hline $\begin{array}{c}\text { Benthic invertebrate } \\
\text { feeders (1) }\end{array}$ & + & + & + & + & + & + & + & + & + \\
\hline $\begin{array}{l}\text { Benthic invertebrate } \\
\text { feeders (2) }\end{array}$ & + & + & + & + & + & + & + & + & + \\
\hline Mullets & + & + & + & + & + & + & + & + & + \\
\hline Piscivorous Fish & + & + & + & + & + & + & + & + & + \\
\hline Sparidae & & & & + & + & + & + & + & + \\
\hline Macro-carnivorous Fish (1) & + & + & + & + & + & + & + & + & + \\
\hline Macro-carnivorous Fish (2) & + & + & + & + & + & + & + & + & + \\
\hline Rays (1) & + & + & + & + & + & + & + & + & + \\
\hline Rays (2) & + & + & + & + & + & + & + & + & + \\
\hline Sharks & + & + & + & + & + & + & + & + & + \\
\hline Small tuna & + & + & + & + & + & + & + & + & + \\
\hline Medium pelagic fish & + & + & + & + & + & + & + & + & + \\
\hline Atlantic bluefin tuna & + & + & + & + & + & + & + & + & + \\
\hline Dolphins & + & + & + & + & + & + & + & + & + \\
\hline Sea birds & + & + & + & + & + & + & + & + & + \\
\hline
\end{tabular}

Table 2. Suitability of habitat types for fishing fleets in the Gulf of Gabes Ecospace model. (+) sign indicates fishable habitat.

\begin{tabular}{|c|c|c|c|c|c|c|c|c|c|}
\hline \multicolumn{10}{|c|}{ Habitat type (depth range) } \\
\hline \multirow{2}{*}{ Fishing fleet } & \multirow{2}{*}{$\begin{array}{c}\begin{array}{c}\text { Deep } \\
\text { mud }\end{array} \\
(<100 \mathrm{~m})\end{array}$} & \multirow{2}{*}{$\begin{array}{l}\text { Offshore muddy } \\
\text { sand and gravel } \\
(<100 \mathrm{~m})\end{array}$} & \multicolumn{4}{|c|}{ Circalittoral bioclastic muddy sand } & \multirow{2}{*}{$\begin{array}{c}\begin{array}{c}\text { Posidonia } \\
\text { high density }\end{array} \\
(20-35 \mathrm{~m})\end{array}$} & \multirow{2}{*}{$\begin{array}{c}\text { Posidonia } \\
\text { medium density }\end{array}$} & \multirow{2}{*}{$\begin{array}{r}\begin{array}{r}\text { Posidonia } \\
\text { low density }\end{array} \\
(20-35 \mathrm{~m})\end{array}$} \\
\hline & & & $(20-35 \mathrm{~m})$ & $(35-50 \mathrm{~m})$ & $(50-100 \mathrm{~m})$ & $(<100 \mathrm{~m})$ & & & \\
\hline Coastal fishing & & & + & + & + & & + & + & + \\
\hline Lamparo & + & + & & + & + & + & & + & \\
\hline Small seine & + & + & + & + & + & + & + & + & + \\
\hline Tuna purse seine & + & + & & + & + & + & & + & \\
\hline Bottom trawling & + & + & & & + & + & & & \\
\hline Sponge fishing & & & + & & & & + & & + \\
\hline
\end{tabular}



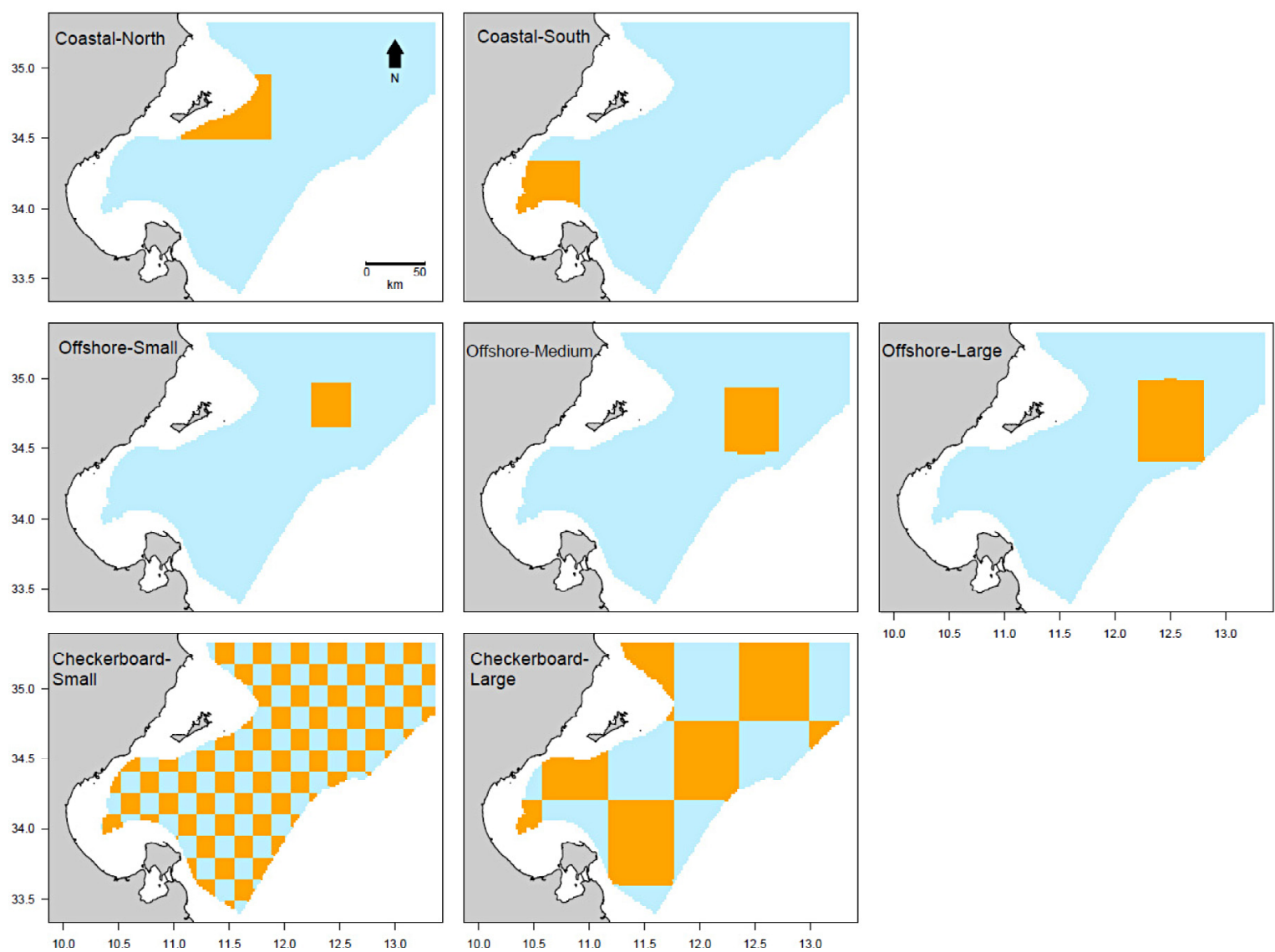

Fig. 3. Maps for spatial distribution of MPAs for the scenarios compared in this study. Orange represents the MPA, blue and orange the study area, and grey land.

find and consume appropriate food. We assumed the following values: 0.95 for functional groups with a trophic level equal to 1 (primary producers) because the habitat type slightly influences the feeding ability of these organisms, 0.01 for species with a trophic level between 2 and 3.5, 0.3 for species with a trophic level between 3.5 and 4 , and 0.6 for species with a trophic level greater than 4 (Fouzai et al. 2012) (see Annex 3 for details).

\subsection{Spatial management scenarios}

Three sets of spatial scenarios were tested for the location of MPAs from which all types of fishing are excluded (Fig. 3). All scenarios were applied over the period 1995-2010. The results were compared to the reference scenario with no MPA, reflecting the present situation in the Gulf of Gabes, to explore the potential effects of the establishment of an MPA on the ecosystem. Note that the studied MPA designs do not reflect desired or planned management plans, but rather represent contrasting scenarios for the spatial distribution of closed areas.

- Coastal MPAs. In the Coastal-North scenario, an MPA covering $1900 \mathrm{~km}^{2}$ is implemented in the Northern part of the gulf while in the Coastal-South scenario the same surface is protected further to the South (Fig. 3). The aim of these scenarios was to assess the effect of MPA location.
- Offshore MPAs. Three offshore MPA scenarios with different surface areas were implemented, Offshore-Small covering an area of $1300 \mathrm{~km}^{2}$, Offshore-Medium $2600 \mathrm{~km}^{2}$, and Offshore-Large $3900 \mathrm{~km}^{2}$ (Fig. 3). These scenarios provided insight into the importance of MPA size.

- Checkerboard MPAs. Two regular checkerboard configurations were assessed, with many small MPAs for Checkerboard-Small and fewer larger MPAs for Checkerboard-Large (Fig. 3). These scenarios were used to investigate the role of MPA size and distribution.

For all scenarios total biomass by functional group and catches in 2010 were compared to the values obtained for the reference scenario.

\section{Results}

\subsection{Reference scenario}

After simulating the reference scenario (no MPA) for 15 years, total species biomass and total catches were $17 \%$ and $19 \%$ lower respectively compared to the beginning of the period (Table 3 ). The results showed changes in biomass for functional groups of commercial and ecological importance, with severe declines in cephalopod groups, mantis shrimp, caramote prawn, and deep shrimp (Table 3 ). The majority of 
Table 3. Ecospace simulation results for reference scenario (no MPA). Biomass and catch values by functional group. Biomass values are expressed in t. $\mathrm{km}^{2}$ and catch value in $\mathrm{t} . \mathrm{km}^{2} \cdot \mathrm{y}^{-1}$. Red represents a decrease and green represents an increase of biomasses and catches in 2010 compared to 1995 .

\begin{tabular}{|c|c|c|c|c|c|c|}
\hline Functional group & $\begin{array}{c}\text { Biomass } \\
\text { (1995) }\end{array}$ & $\begin{array}{c}\text { Biomass } \\
(2010)\end{array}$ & $\begin{array}{c}\text { Biomass } \\
\text { ratio } \\
(2010 / 1995) \\
\end{array}$ & $\begin{array}{l}\text { Catch } \\
(1995)\end{array}$ & $\begin{array}{l}\text { Catch } \\
(2010)\end{array}$ & $\begin{array}{l}\text { Catch ratio } \\
(2010 / 1995)\end{array}$ \\
\hline Phytoplankton & 5.54 & 5.18 & 0.93 & & & \\
\hline Macro-algae & 1.34 & 1.16 & 0.86 & & & \\
\hline Posidonia oceanica & 0.02 & 0.01 & 0.70 & & & \\
\hline Micro- and mesozooplankton & 6.45 & 6.81 & 1.06 & & & \\
\hline Macrozooplankton & 2.90 & 2.33 & 0.80 & & & \\
\hline Foraminifera & 0.34 & 0.48 & 1.41 & & & \\
\hline Invertebrate suspension feeders & 6.51 & 4.61 & 0.71 & 0.04 & 0.07 & 1.60 \\
\hline Polychaetes & 3.95 & 4.09 & 1.04 & & & \\
\hline Amphipoda and Isopoda & 4.60 & 3.19 & 0.69 & 0.00 & 0.00 & 1.36 \\
\hline Echinoderms & 4.26 & 2.37 & 0.56 & 0.03 & 0.02 & 0.85 \\
\hline Benthic molluscs & 3.92 & 3.10 & 0.79 & 0.01 & 0.01 & 1.42 \\
\hline Crabs & 2.20 & 1.39 & 0.63 & 0.01 & 0.00 & 0.69 \\
\hline Benthic cephalopods & 0.27 & 0.12 & 0.43 & 0.10 & 0.07 & 0.67 \\
\hline Benthopelagic cephalopods & 0.07 & 0.04 & 0.58 & 0.00 & 0.00 & 0.85 \\
\hline Mantis shrimp & 0.59 & 0.30 & 0.51 & 0.10 & 0.00 & 0.05 \\
\hline Caramote prawn & 0.12 & 0.03 & 0.27 & 0.13 & 0.01 & 0.07 \\
\hline Alien shrimps & 0.12 & 0.20 & 1.62 & 0.04 & 0.02 & 0.68 \\
\hline Deep shrimps & 0.01 & 0.00 & 0.25 & 0.01 & 0.01 & 0.60 \\
\hline Horse mackerel & 1.50 & 1.06 & 0.70 & 0.03 & 0.02 & 0.86 \\
\hline European pilchard & 3.55 & 2.47 & 0.70 & 0.17 & 0.15 & 0.89 \\
\hline Round sardinella & 1.76 & 1.34 & 0.76 & 0.24 & 0.29 & 1.20 \\
\hline European anchovy & 0.65 & 0.58 & 0.89 & 0.00 & 0.01 & 1.63 \\
\hline Picarel & 0.59 & 0.70 & 1.20 & 0.02 & 0.03 & 2.07 \\
\hline Bogue & 0.50 & 0.42 & 0.84 & 0.03 & 0.03 & 1.13 \\
\hline Benthic invertebrate feeders (1) & 0.22 & 0.39 & 1.75 & 0.06 & 0.05 & 0.80 \\
\hline Benthic invertebrate feeders (2) & 0.05 & 0.05 & 0.98 & 0.01 & 0.02 & 1.19 \\
\hline Mullets & 0.10 & 0.10 & 1.00 & 0.07 & 0.04 & 0.60 \\
\hline Piscivorous Fish & 0.07 & 0.06 & 0.83 & 0.00 & 0.00 & 1.69 \\
\hline Sparidae & 0.19 & 0.11 & 0.59 & 0.03 & 0.03 & 0.95 \\
\hline Macro-carnivorous Fish (1) & 0.20 & 0.14 & 0.71 & 0.06 & 0.04 & 0.70 \\
\hline Macro-carnivorous Fish (2) & 0.05 & 0.04 & 0.79 & 0.01 & 0.01 & 0.65 \\
\hline Rays (1) & 0.36 & 0.30 & 0.82 & 0.01 & 0.01 & 1.41 \\
\hline Rays (2) & 0.13 & 0.08 & 0.60 & 0.00 & 0.00 & 1.04 \\
\hline Sharks & 0.19 & 0.09 & 0.47 & 0.01 & 0.01 & 0.81 \\
\hline Small tuna & 0.08 & 0.05 & 0.67 & 0.03 & 0.02 & 0.71 \\
\hline Medium pelagic fish & 1.47 & 1.22 & 0.83 & 0.09 & 0.09 & 1.02 \\
\hline Atlantic bluefin tuna & 0.23 & 0.21 & 0.88 & 0.06 & 0.04 & 0.64 \\
\hline Dolphins & 0.08 & 0.05 & 0.66 & & & \\
\hline Sea birds & 0.00 & 0.00 & 0.63 & & & \\
\hline Discards & 0.36 & 0.26 & 0.74 & & & \\
\hline Detritus & 23.20 & 20.49 & 0.88 & & & \\
\hline Total & 78.77 & 65.64 & 0.83 & 1.39 & 1.12 & 0.81 \\
\hline
\end{tabular}



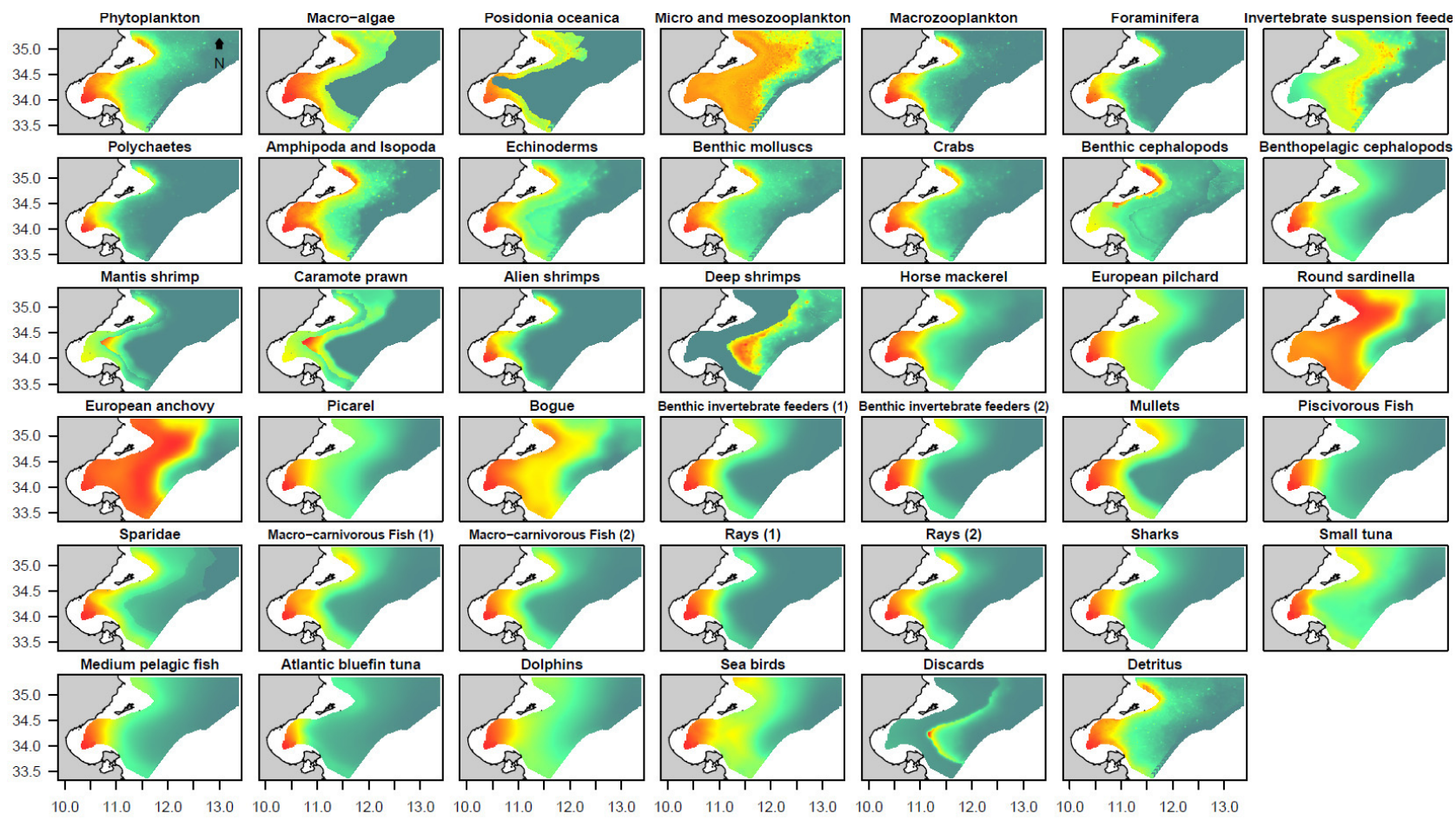

Alien shrimps
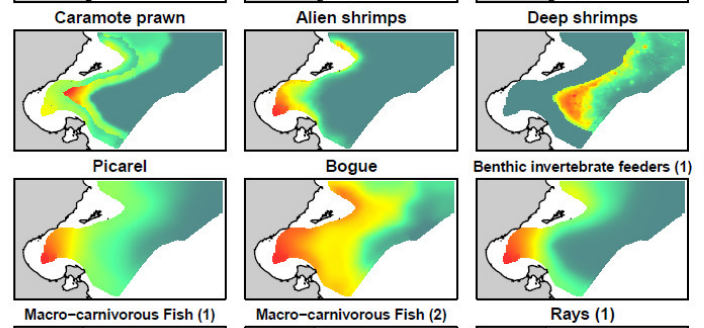

Horse mackere

European pilchard
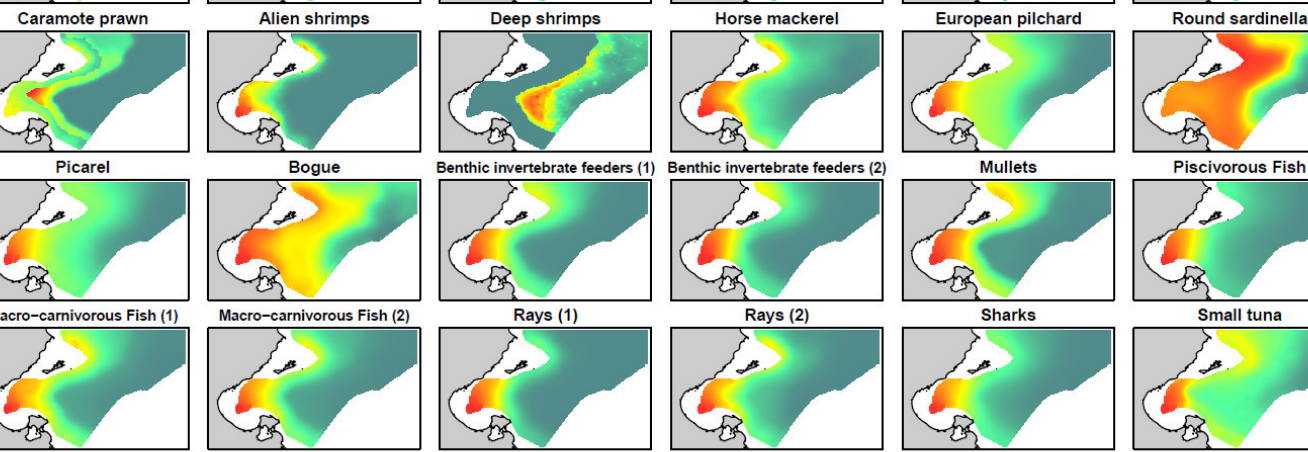

Atlantic bluefin tuna
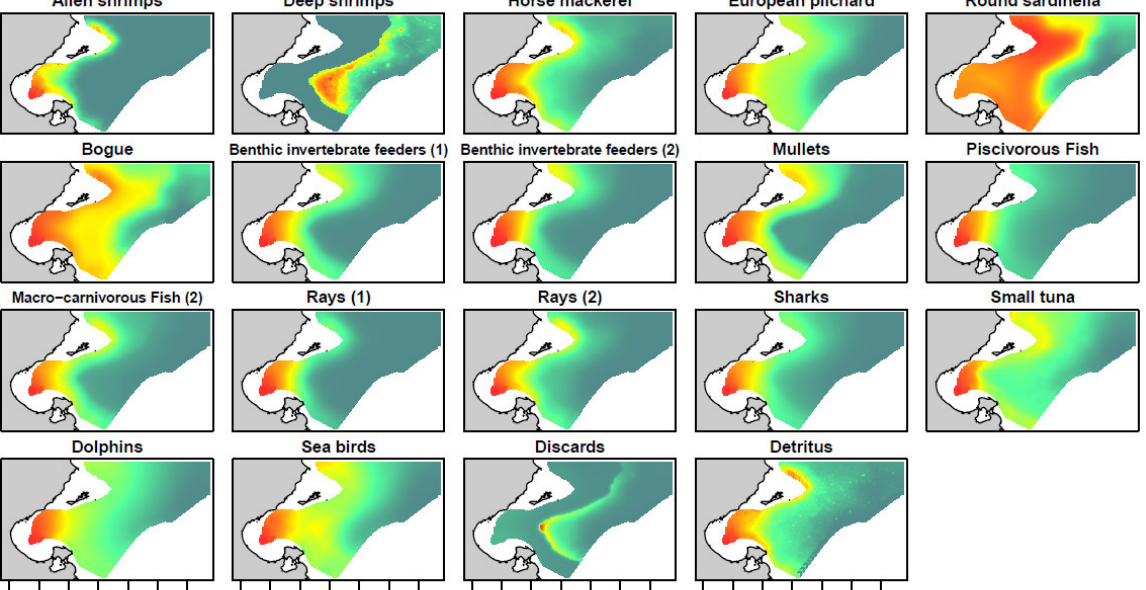

Rays (2)
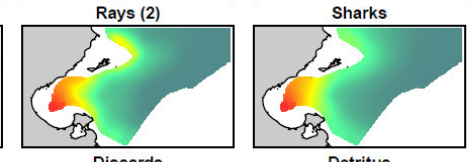

Small tuna
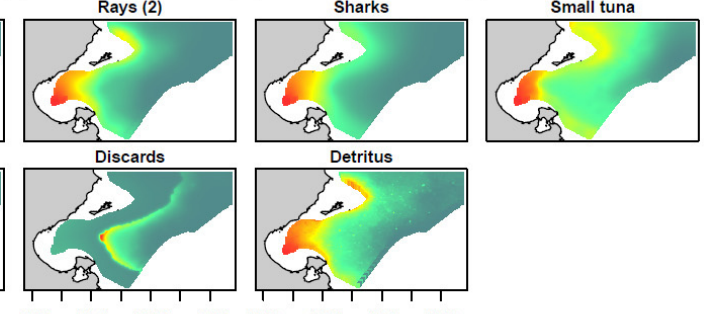

Fig. 4. Ecospace model predictions of the spatial distribution of biomass for each functional group in the Gulf of Gabes at the end of the 15-year simulation period (2010) for the reference scenario with no MPA. Colors represent relative densities in t.km ${ }^{-2}$.

predator groups exhibited a major decline in biomass, which was most acute for sharks; using the Ecopath model it has been shown that sharks are a keystone group in the Gulf of Gabes ecosystem (Hattab et al. 2013a). However, some exceptions can be noted with some groups having marginally increased biomass. The spatial distribution of functional groups at the end of the simulation period (2010) revealed local depletions of several species, especially in the open sea (Fig. 4).

Regarding catches, many groups showed an increase over the simulation period with catches being multiplied by a factor between 1.2 to 2.5 for groups with an intermediate trophic level such as round sardinella, European anchovy, picarel and bogue (Table 3). However, catches for other groups declined, especially for the commercially targeted demersal species (rays and sharks).

\subsection{MPAs implementation simulations}

\section{Coastal MPA scenarios}

Total biomass for the Coastal-North MPA scenario at the end of the simulation period was nearly identical $(-0.05 \%)$ to the biomass obtained for the reference scenario (Table 4). However, the biomass of several species was larger when the MPA was implemented, such as for benthic invertebrate feeders $(2)(+14 \%)$, picarel $(+6 \%)$, small tuna $(+2.5 \%)$, sharks $(+2 \%)$, medium pelagic fish $(+1.5 \%)$ and Atlantic bluefin tuna $(+1.2 \%)$. In contrast, other groups responded to the MPA with a decline in their biomasses, such as caramote prawn $(-11 \%)$, mullets $(-5 \%)$, mantis shrimp $(-4 \%)$, macrocarnivorous fish (2) $(-2 \%)$ and alien shrimp $(-1.6 \%)$. The establishment of the MPA led to an $11 \%$ increase in the total catch with a substantial increase in the catches for all groups, except European pilchard, round sardinella, European anchovy and bogue (Table 4).

The results for the Coastal-South MPA scenario were similar with basically no change $(+0.11 \%)$ in total biomass and larger biomasses, especially for commercially targeted groups of benthic invertebrate feeders (2) (+89\%), piscivorous fish $(+38 \%)$, rays $(1)(+14 \%)$, Atlantic bluefin tuna $(+5 \%)$, small tuna $(+3 \%)$ and medium pelagic fish $(+2.5 \%)$. Similar functional groups exhibited a lower biomass, such as macro-carnivorous fish (1) $(-5 \%)$ and (2) $(-8 \%)$, mantis shrimp $(-5.5 \%)$, caramote prawn $(-5 \%)$, sparidae $(-2.5 \%)$, picarel $(-2.5 \%)$, European pilchard $(-2 \%)$ and mullets $(-2 \%)$. Total catches were $4 \%$ lower for this coastal MPA scenario, and the decline concerned nearly all functional groups, except benthic invertebrate feeders (2), piscivorous fish and European anchovy (Table 4).

Comparing the two implementations of a coastal MPA showed a difference in the response of functional groups. For several groups, the increase in biomass, compared to the reference scenario, was more pronounced when implementing the Coastal-North MPA than the scenario with the Coastal-South MPA. For instance, benthic invertebrate feeders (2) exhibited a $14 \%$ increase in the first scenario and $89 \%$ in the second. The biomass of the piscivorous fish group did not change in the Coastal-North MPA while it increased by $38 \%$ for the southern MPA. For some other groups, biomass increased when implementing the Coastal-North MPA and decreased for the 
Table 4. Ecospace simulation results for MPA scenarios compared to the reference scenario (no MPA). Biomass and catch ratios at the end of the simulation period (2010) by functional group. Red represents less (ratio < 0.99) and green higher (ratio > 1.01) biomass or catch. For scenario description see Figure 3.

\begin{tabular}{|c|c|c|c|c|c|c|c|c|c|c|c|c|c|c|}
\hline & & & & Biomass & & & & & & & Catch & & & \\
\hline $\begin{array}{l}\text { Functional } \\
\text { group }\end{array}$ & $\begin{array}{l}\text { Coastal- } \\
\text { North }\end{array}$ & $\begin{array}{l}\text { Coastal- } \\
\text { South }\end{array}$ & $\begin{array}{l}\text { Offshore } \\
\text {-Small }\end{array}$ & $\begin{array}{l}\text { Offshore- } \\
\text { Medium }\end{array}$ & $\begin{array}{l}\text { Offshor } \\
\text { e-Large }\end{array}$ & $\begin{array}{l}\text { Checker } \\
\text { board- } \\
\text { Small } \\
\end{array}$ & $\begin{array}{l}\text { Checker } \\
\text { board- } \\
\text { Large }\end{array}$ & $\begin{array}{l}\text { Coastal- } \\
\text { North }\end{array}$ & $\begin{array}{l}\text { Coastal- } \\
\text { South }\end{array}$ & $\begin{array}{l}\text { Offshore } \\
\text {-Small }\end{array}$ & $\begin{array}{l}\text { Offshore- } \\
\text { Medium }\end{array}$ & $\begin{array}{l}\text { Offshore } \\
\text {-Large }\end{array}$ & $\begin{array}{l}\text { Checker } \\
\text { board- } \\
\text { Small } \\
\end{array}$ & $\begin{array}{l}\text { Checker } \\
\text { board- } \\
\text { Large }\end{array}$ \\
\hline Phytoplankton & 1.0002 & 1.0006 & 1.0000 & 1.0000 & 0.9999 & 1.0002 & 1.0012 & & & & & & & \\
\hline Macro-algae & 1.0060 & 1.0105 & 0.9989 & 0.9968 & 0.9953 & 1.0056 & 1.0142 & & & & & & & \\
\hline Posidonia oceanica & 1.0174 & 1.0274 & 1.0031 & 1.0022 & 1.0021 & 1.0106 & 1.0513 & & & & & & & \\
\hline Micro- and mesozooplankton & 0.9986 & 1.0019 & 0.9991 & 0.9990 & 0.9990 & 1.0007 & 1.0021 & & & & & & & \\
\hline Macrozooplankton & 0.9889 & 0.9940 & 0.9994 & 1.0009 & 1.0022 & 0.9963 & 0.9785 & & & & & & & \\
\hline Foraminifera & 1.0074 & 1.0283 & 0.9981 & 0.9965 & 0.9950 & 1.0063 & 1.0385 & & & & & & & \\
\hline Invertebrate suspension feeders & 1.0087 & 1.0202 & 1.0009 & 1.0015 & 1.0021 & 1.0084 & 1.0463 & 1.1606 & 1.0040 & 0.9793 & 0.9945 & 1.0052 & 0.9895 & 0.8246 \\
\hline Polychaetes & 0.9983 & 0.9743 & 1.0007 & 1.0012 & 1.0016 & 0.9945 & 0.9718 & & & & & & & \\
\hline Amphipoda and Isopoda & 1.0007 & 1.0000 & 1.0009 & 1.0020 & 1.0031 & 0.9992 & 0.9992 & 1.0225 & 0.9517 & 0.9962 & 0.9838 & 0.9783 & & \\
\hline Echinoderms & 0.9729 & 0.9807 & 0.9916 & 0.9909 & 0.9888 & 0.9770 & 0.8780 & 1.1052 & 0.9837 & 0.9947 & 1.0200 & 1.0403 & 0.8658 & 0.6585 \\
\hline Benthic molluscs & 1.0003 & 1.0048 & 0.9985 & 0.9978 & 0.9970 & 1.0008 & 1.0024 & 1.0716 & 0.9426 & 0.9947 & 0.9891 & 0.9889 & 0.8851 & 0.7794 \\
\hline Crabs & 0.9928 & 0.9824 & 0.9992 & 0.9998 & 1.0000 & 0.9903 & 0.9587 & 1.1638 & 1.0005 & 1.0118 & 1.0389 & 1.0676 & 0.9756 & 0.8395 \\
\hline Benthic cephalopods & 0.9874 & 0.9895 & 0.9971 & 0.9967 & 0.9940 & 0.9787 & 0.9452 & 1.0792 & 0.9752 & 0.9848 & 0.9775 & 0.9983 & 0.6823 & 0.4565 \\
\hline Benthopelagic cephalopods & 1.0031 & 1.0000 & 0.9976 & 0.9920 & 0.9876 & 1.0069 & 1.0220 & 1.1590 & 0.9335 & 1.0075 & 1.0239 & 1.0387 & 0.8377 & 0.6755 \\
\hline Mantis shrimp & 0.9644 & 0.9454 & 1.0019 & 1.0033 & 1.0062 & 1.0051 & 0.9281 & 1.4217 & 1.0014 & 1.0299 & 1.0734 & 1.0853 & 1.3052 & 0.7896 \\
\hline Caramote prawn & 0.8934 & 0.9513 & 1.0347 & 1.0115 & 1.0122 & 1.1200 & 1.2303 & 1.3145 & 0.8956 & 1.0298 & 1.0965 & 1.1240 & 0.9668 & 0.5681 \\
\hline Alien shrimps & 0.9842 & 0.9544 & 1.0000 & 0.9995 & 1.0006 & 0.9885 & 0.9561 & 1.3855 & 0.7106 & 1.0345 & 1.0705 & 1.0822 & 0.0376 & 0.0343 \\
\hline Deep shrimps & 1.0019 & 1.0009 & 0.9772 & 0.9643 & 0.9513 & 0.9214 & 0.8081 & 1.0855 & 1.0012 & 0.9798 & 0.9895 & 1.0007 & 0.7972 & 0.5724 \\
\hline Horse mackerel & 0.9927 & 0.9973 & 0.9982 & 0.9984 & 0.9984 & 0.9977 & 0.9831 & 1.0079 & 0.9392 & 1.0085 & 1.0233 & 1.0376 & 1.0445 & 0.9430 \\
\hline European pilchard & 1.0010 & 1.0198 & 0.9975 & 0.9943 & 0.9916 & 1.0093 & 1.0428 & 0.9897 & 0.9604 & 1.0058 & 1.0156 & 1.0236 & 1.3205 & 1.1899 \\
\hline Round sardinella & 0.9941 & 1.0029 & 0.9980 & 0.9976 & 0.9969 & 1.0022 & 0.9958 & 0.9785 & 0.9963 & 0.9938 & 0.9971 & 0.9987 & 1.1852 & 1.0254 \\
\hline European anchovy & 0.9953 & 1.0008 & 0.9985 & 0.9993 & 0.9998 & 1.0004 & 0.9998 & 0.9912 & 1.0107 & 0.9969 & 1.0019 & 1.0050 & 1.0963 & 0.9762 \\
\hline Picarel & 1.0601 & 0.9742 & 1.0112 & 1.0084 & 1.0063 & 1.0016 & 1.0381 & 1.2330 & 0.9581 & 1.0108 & 1.0179 & 1.0241 & 0.8900 & 0.7835 \\
\hline Bogue & 0.9961 & 0.9977 & 0.9987 & 0.9993 & 0.9996 & 0.9993 & 0.9933 & 0.9927 & 0.9819 & 0.9986 & 1.0044 & 1.0095 & 1.3420 & 1.2257 \\
\hline Benthic invertebrate feeders (1) & 1.0117 & 0.9417 & 1.0193 & 1.0246 & 1.0343 & 1.0032 & 1.1352 & 1.4792 & 0.9689 & 1.0035 & 1.0164 & 1.0236 & 0.9410 & 0.8622 \\
\hline Benthic invertebrate feeders (2) & 1.1398 & 1.8893 & 0.9716 & 0.9467 & 0.9252 & 1.1891 & 2.0725 & 1.3130 & 1.3008 & 0.9702 & 0.9541 & 0.9381 & 0.3731 & 0.4411 \\
\hline Mullets & 0.9534 & 0.9766 & 1.0134 & 1.0173 & 1.0249 & 1.0052 & 1.1329 & 1.2948 & 0.9637 & 0.9954 & 1.0170 & 1.0359 & 0.8458 & 0.6784 \\
\hline Piscivorous Fish & 1.0034 & 1.3815 & 0.9935 & 0.9865 & 0.9807 & 1.0416 & 1.2356 & 1.0425 & 1.0542 & 0.9972 & 0.9947 & 0.9919 & 0.5490 & 0.5603 \\
\hline Sparidae & 0.9984 & 0.9762 & 1.0011 & 1.0027 & 1.0036 & 0.9971 & 0.9678 & 1.0679 & 0.8780 & 1.0048 & 1.0090 & 1.0102 & 0.6616 & 0.6234 \\
\hline Macro-carnivorous Fish (1) & 1.0051 & 0.9510 & 1.0079 & 1.0132 & 1.0199 & 0.9979 & 1.0377 & 1.2839 & 0.9418 & 0.9968 & 1.0088 & 1.0168 & 0.7946 & 0.6171 \\
\hline Macro-carnivorous Fish (2) & 0.9804 & 0.9201 & 1.0083 & 1.0158 & 1.0234 & 0.9706 & 0.9354 & 1.2873 & 0.9543 & 0.9921 & 1.0053 & 1.0148 & 0.8873 & 0.6560 \\
\hline Rays (1) & 1.0026 & 1.1378 & 0.9937 & 0.9891 & 0.9846 & 1.0201 & 1.0914 & 1.1800 & 0.7352 & 1.0075 & 1.0120 & 1.0166 & 0.1576 & 0.1241 \\
\hline Rays (2) & 1.0101 & 0.9929 & 0.9992 & 0.9974 & 0.9960 & 1.0001 & 0.9963 & 1.1486 & 0.8509 & 1.0084 & 1.0190 & 1.0287 & 0.4814 & 0.3438 \\
\hline Sharks & 1.0205 & 0.9539 & 1.0021 & 1.0004 & 0.9993 & 1.0055 & 1.0167 & 1.1838 & 0.8155 & 1.0095 & 1.0164 & 1.0287 & 0.4999 & 0.4001 \\
\hline Small tuna & 1.0239 & 1.0287 & 0.9981 & 0.9963 & 1.0012 & 1.0190 & 1.0668 & 0.9974 & 0.9364 & 0.9970 & 0.9990 & 1.0032 & & \\
\hline Medium pelagic fish & 1.0152 & 1.0235 & 1.0011 & 1.0022 & 1.0060 & 1.0089 & 1.0352 & 1.0157 & 0.9564 & 1.0021 & 1.0031 & 1.0030 & 1.2069 & 1.1322 \\
\hline Atlantic bluefin tuna & 1.0117 & 1.0496 & 1.0041 & 1.0169 & 1.0386 & 1.0385 & 1.2342 & 1.0002 & 0.9827 & 1.0038 & 1.0125 & 1.0203 & & \\
\hline Dolphins & 1.0082 & 1.0024 & 0.9999 & 0.9981 & 0.9967 & 1.0052 & 1.0231 & & & & & & & \\
\hline Sea birds & 1.0190 & 1.1186 & 1.0016 & 1.0010 & 1.0020 & 0.9630 & 1.0574 & & & & & & & \\
\hline Discards & 0.9617 & 0.9816 & 0.9934 & 1.0040 & 1.0099 & 0.9996 & 0.8690 & & & & & & & \\
\hline Detritus & 1.0000 & 1.0003 & 0.9999 & 0.9998 & 0.9996 & 1.0002 & 1.0006 & & & & & & & \\
\hline Total & 0.9995 & 1.0011 & 0.9996 & 0.9996 & 0.9997 & 1.0003 & 1.0011 & 1.1068 & 0.9658 & 1.0031 & 1.0184 & 1.0286 & 0.6460 & 0.5644 \\
\hline
\end{tabular}



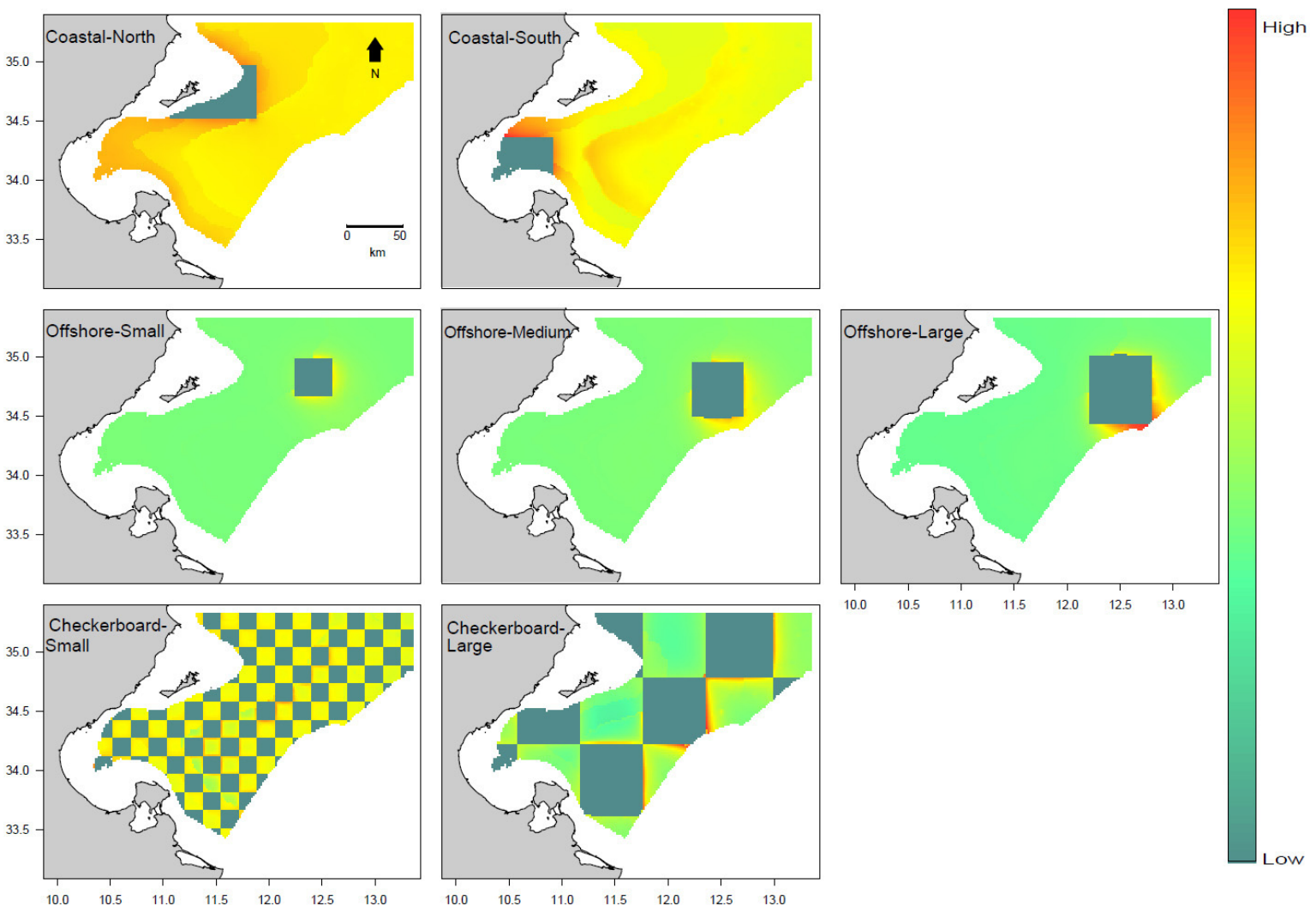

Fig. 5. Spatial distribution of the total catches in the Gulf of Gabes ecosystem at the end of the simulation period (2010) for different MPA scenarios; see Figure 3 for a description of scenarios. MPAs closed to fishing are represented in blue.

Coastal-South MPA, such as picarel (+6\% vs. $-2.5 \%)$, benthic invertebrate feeders $(1)(+1.2 \%$ vs. $-6 \%)$ and sharks $(+2 \%$ vs. $-5 \%)$. Total catches increased by $+11 \%$ for the CoastalNorth scenario and decreased by $-4 \%$ for the northern MPA. The catches of the majority of functional groups increased for the Coastal-North scenario, while they decreased for the Coastal-South scenario. This difference was marked for alien shrimp with a $+38 \%$ increase in catches for the northern MPA compared to a $29 \%$ decrease for the southern MPA.

\section{Offshore MPA scenarios}

The main purpose of these offshore MPA scenarios was to understand the effect of MPA size on functional group biomass and catches. In response to the implementation of the three different-sized MPAs, some groups benefitted from MPA size expansion, such as benthic invertebrate feeders (1), mullets, Atlantic bluefin fish and macro-carnivorous fish (1) and (2). The implementation of the MPA resulted in a decline in the biomass of some groups, such as deep shrimps, benthic invertebrate feeders (2), piscivorous fish and rays (1). Furthermore, total biomass decreased compared to the reference scenario, $0.4 \%, 0.4 \%$ and $0.3 \%$ respectively for increasing MPA size. Regarding catches, in total, the harvested biomass increased with MPA size, by $+0.3 \%,+1.8 \%$ and $+2.9 \%$ respectively, and this was the general trend for the majority of the groups, except benthic invertebrate feeders (2) (Table 4).

\section{Checkerboard MPA scenarios}

For these scenarios, the same surface area was protected using a checkerboard pattern but with differences with respect to the size of each MPA (many small or fewer large). The outcomes showed that, for most groups, final year biomass was larger compared to the reference scenario, with the exception of alien shrimp, deep shrimp, mantis shrimp, horse mackerel, Sparidae, macro-carnivorous fish and sea birds. The differences were more marked for the Checkerboard-Large scenario, which had fewer larger MPAs. However, the difference in the total biomass increase was small $(+0.03 \%$ compared to $+0.11 \%)$.

Concerning total catch, a significant decrease was found for both scenarios ( $-35 \%$ and $-44 \%$ respectively). This could be explained by the fact that approximately half of the Gulf of Gabes was protected in both scenarios. The catches of some groups increased for small-sized MPAs, but decreased for the larger MPAs, e.g. for mantis shrimp, horse mackerel and European anchovy. For most groups the decrease in catches was much more marked when the checkerboard consisted of larger MPAs (Table 4).

\section{Spatial distribution of total catch and biomass}

To explore the redistribution of fishing efforts when an MPA was implemented, maps were drawn for the spatial distribution of total catches at the end of the simulation period (2010) for each investigated scenario (Fig. 5). The results 

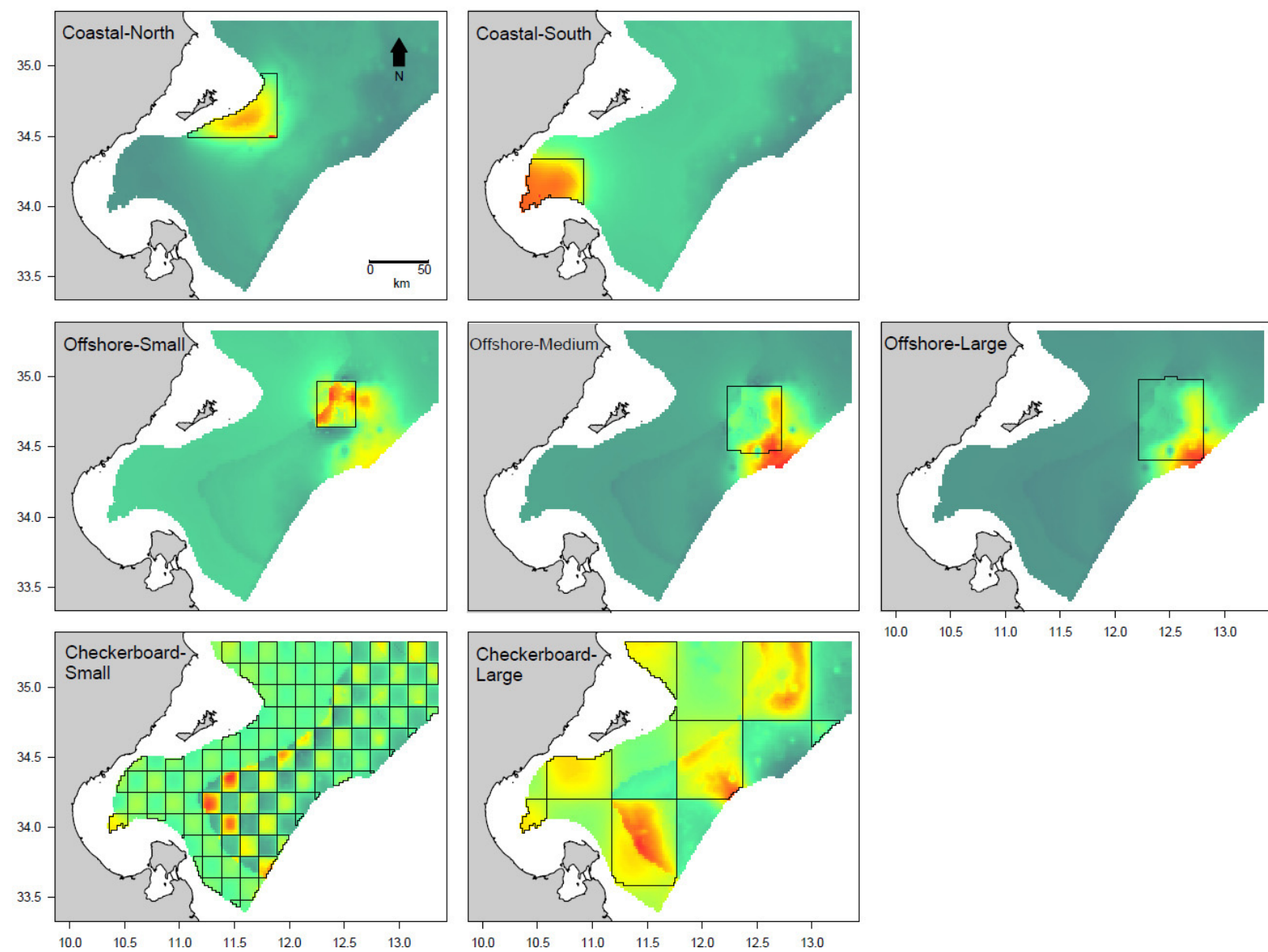

Fig. 6. Spatial distribution of the total biomass in the Gulf of Gabes ecosystem at the end of the simulation period (2010) for different MPA scenarios; see Figure 3 for a description of scenarios. Boxes delimit MPAs closed to fishing.

showed a concentration of catches and thus fishing activity in the areas adjacent to the MPAs, with the degree of increase in catches next to MPAs differing between scenarios, indicating differences in the "spillover" effect. The spatial distribution of total biomass was also mapped (Fig. 6). Total biomass was always higher inside the MPAs and in the adjacent areas, but with differences between scenarios.

\section{Discussion}

Recognizing the global depletion of fish resources, it has become necessary to develop adequate complementary methods for managing fisheries (Halpern et al. 2008; Pitcher and Cheung 2013). To this end, modeling is considered a valuable tool to help make decisions for conserving and exploiting marine resources (Christensen and Walters 2004). This study uses a spatio-temporal modeling framework to evaluate the effects generated by the establishment of MPAs on ecosystem structure, through trophic cascades and links between different functional groups. The model also provided insights into how species-specific biomasses and catches could change for each of the tested management scenarios.

For the Northern-Central Adriatic Sea ecosystem Fouzai et al. (2012) simulated realistic MPA scenarios using an
Ecospace model. In contrast, the scenarios assessed in this study cannot be implemented and were only intended to help understand the ecosystem. Another major difference is that the Adriatic Ecospace model scenarios simulated a seasonal fishing ban and a reduction in fishing effort while here we only explored permanent fishing bans and status quo fishing effort.

\section{Current fishery state}

The results of this study indicated that given the current fishery state in the Gulf of Gabes, the depletion of marine resources was more severe in 2010 , i.e. at the end of the 15 -year simulation period. This conclusion agrees with what was deduced from the Ecopath model by Hattab et al. (2013a), in which all of the assessed indicators showed that the area is unsustainably fished.

The results highlighted that most of the predator species with high and medium trophic levels had lower abundance after the 15-year simulation, which explains the increase in their prey. These results are in agreement with the findings obtained with an Ecotroph model reported in Halouani et al. (2015).

The outcomes of the reference scenario showed a major increase in the biomass of the alien Lessepsian shrimp 
group (Trachysalambria curvirostris and Metapenaeus monoceros). This group is in direct trophic competition with the native caramote prawn because both groups have similar prey and predators, leading to a partial trophic niche overlap (Ben Abdallah et al. 2003). As a result of this competitive relationship, a reduction in the biomass of caramote prawn occurred. Other shrimp groups exhibited a similar decline (mantis shrimp and deep shrimp) following the appearance of alien shrimp in massive numbers. In addition, caramote prawn has a high fishing mortality rate because it is the primary target of bottom trawlers. These finding are in agreement with previous conclusions (Ben Abdallah et al. 2003).

The biomass of predator groups exhibited a dramatic decline, primarily among sharks and rays. Sharks play an important role in the Gulf of Gabes ecosystem, and they are primarily a by-catch species for bottom trawlers (Hattab et al. 2013a; Saïdi et al. 2005). Landings in the Gulf of Gabes occur all year round and they primarily consist of juveniles and near-term pregnant females that approach the coast to give birth in more favorable environmental conditions (Saïdi et al. 2008). Based on official landings statistics collated by the DGPA, elasmobranch catches in the Gulf of Gabes region represent $2.24 \%$ of national fish production, and elasmobranch production has declined since 2002, despite increased fishing effort in the area.

\section{Scenarios discussion}

To safeguard marine resources and help in the recovery of overexploited stocks, MPAs are increasingly promoted as an effective management strategy. Marine reserves provide a precautionary approach to halt the overexploitation of fish stocks (Chen et al. 2009; Murray et al. 1999). MPAs minimize the impact of fisheries on ecosystems by protecting sensitive habitats and providing refuge for endangered species. They also insure better fishery stability by closing the gap between the yield and stock capacity, which can reconstitute itself (Ward et al. 2001). Nonetheless, the implementation of MPAs closed to fishing does not necessarily benefit the ecosystem (Le Quesne et al. 2007), and some unexpected results have been reported. For example, when the conditions within the protected area favor the increase of predator populations, prey biomass will decline, leading to the so-called trophic cascade. In the short term, closed areas can result in lower catches, and fishermen may be obliged to sail further to reach fishing grounds. However, on the economic side, the loss of catches could be compensated for when species with higher commercial values are targeted. Indeed, the benefits within and outside the closed areas might be reached in the long term, after a long period of protection (Abesamis and Russ 2005; Colléter et al. 2014).

Despite their popularity and historical use, field evidence for the impacts of MPAs on species biomass and fishery yields remains elusive. Therefore, ecosystem modeling can help evaluate the effectiveness of management plans before implementation (Hilborn et al. 2006). The Ecospace model can be used to evaluate the effects of a given management option and provide insights into where to place protected areas and how to design them (Salomon et al. 2002).

Comparing the two coastal MPA scenarios with the reference scenario indicated a decrease in total biomass for the more northern MPA, but with an increase in total catch, and an increase in total biomass and a decline in total yield for the more southerly located MPA. Thus, it can be concluded that the location of the MPA influences the benefits gained from MPA establishment, which is directly related to the habitats that occur in the protected area. Several studies have shown that the implementation of a successful MPA requires good knowledge of the location and type of habitats (Dugan and Davis 1993; Friedlander and Parrish 1998; Guizien et al. 2012). This result is also in agreement with the results of Hattab et al. (2013b), who used a new method based on the fuzzy logic framework to identify favorable areas in the Gulf of Gabes in which to place artificial anti-trawling reefs. Their results showed that the choice of the location and the spatial arrangement of the reefs is crucial and should be carefully planned to ensure the intended conservation of the ecosystem (Hattab et al. 2013b).

The primary goal of the offshore MPA scenarios was to consider the influence of MPA size. Accordingly, the implemented MPAs had relative sizes of 1,2 and 3. Comparing these scenarios with the reference scenario did not show any differences concerning total biomass. In a study conducted by Halpern (2003), in which he reviewed the empirical results of 89 different MPAs to assess the impact of MPAs on different biological measures, the results showed that, on average, the size of the protected area did not influence the increase in species abundances or biomasses. However, for total catch we observed a significant gain when we increased the size of the MPA, multiplying the total catch by 1.0031 for a small offshore MPA, by 1.0184 for a medium-sized MPA and by 1.0286 for a large MPA. This result can be explained by the "gravity model" used in the Ecospace model to distribute fishing effort over the modeled area based on fishing profitability, which allows the model to mimic reality in a more accurate and realistic way (Walters et al. 1999). Furthermore, when an MPA is established, the model redistributes the fishing effort rather than reducing it, resulting in a pronounced concentration of fishing activity in the areas adjacent to the MPA. Therefore, an increase in the size of an MPA results in an increase of the boundary and, consequently, an increase in catches. These patterns were also found for other scenarios (Fig. 5).

With the checkerboard scenarios we assessed the effect of MPA shape by implementing two different MPA networks in a checkerboard pattern covering half of the Gulf of Gabes. The first had many small-sized MPAs and the second fewer large ones. The results showed a large decrease in total catch, due to the prohibition of fishing activity over a large area. We can conclude that many small MPAs benefit the fisheries more than the implementation of fewer large MPAs in terms of total catch. However, no large differences were found for the level of total biomass. This conclusion is in line with what has been shown by Aswani and Hamilton (2004). Many other studies showed that a network of small-size MPAs allows for much better protection of marine communities than one large protected area (Hastings and Botsford 2003; Lubchenco et al. 2003). Indeed, the circumference/surface ratio is higher when many small MPAs are implemented, allowing for greater diffusion of species and propagules in the adjacent areas, which is highly beneficial for fishery (Roberts et al. 2003). 
Because MPAs contain more and larger fish, the protected species can potentially produce more than in unprotected areas. From this study it can be concluded that there was a higher concentration of species inside the MPA and in the adjacent areas as a result of the "spillover" effect (Fig. 6). However, we found that the biomass emigrating from the MPA was more pronounced for the southern coastal MPA scenario compared to the northern one, although the size of the MPA remained the same. Indeed, the spillover phenomenon was also related to the types of habitat protected by the MPA. Therefore, in instances when the habitats outside the MPA are suitable for the species inside the protected area, emigration will be greater (as in the Coastal-South scenario) (Tupper 2007). However, in the opposite case, when the adjacent habitats are not as favorable as the ones inside the MPA, the spillover will not have the same intensity and will be lower in terms of biomass (as found for the Coastal-North scenario) (Freeman et al. 2009).

Considering the overall results, the most susceptible groups to change were species with high commercial value and those predominantly targeted by bottom trawlers (benthic invertebrate feeders, mullets, macro-carnivorous fish, piscivorous fish, sharks and rays). Most of these groups are considered to be over- or fully exploited (Ben Meriem et al. 1994; Gharbi et al. 2004; Jarboui et al. 1998); they have an exploitation rate higher than the general reference point (Hattab et al. 2013a). This indicates that the Gulf of Gabes is a highly fished ecosystem. Thus, the establishment of effective management measures (MPAs) is a necessity to remedy the situation.

The results of this study are conditional on a number of factors that might affect the outcomes. First and foremost, there is a strong dependency of the Ecospace model on the underlying Ecopath and Ecosim model. The estimation errors are very large for the parameters of the Ecopath model. Furthermore, given the lack of reliable data the area shallower than the 20-m isobath was excluded, adding more uncertainty to the model results.

The Ecospace model of the Gulf of Gabes did not account for all types of transport processes and excluded migratory behavior and advection due to a lack of data. These factors can be important for the spatial distribution of fish species and their inclusion would provide more accurate and realistic predictions. The study could be completed with a socioeconomic component by defining additional parameters, such as sailing costs and species prices, which would provide an idea about the best management options to halt the depletion of marine resources while maintaining reasonable economic profitability. The robustness of the model could be improved if data concerning the spatial distribution of catches, biomass values and fishing efforts were available. Such data could be used to validate the model.

Although these limitations can potentially compromise the accuracy of the model at a quantitative level, the qualitative information gained from the Ecospace model is still useful and can be utilized by policymakers to make informed decisions (Walters et al. 1999). Finally, the majority of the scenarios assessed in this study are not feasible and do not reflect any planned MPA, but they are a theoretical exercise designed to predict the temporal trends of the ecosystem and to assess its potential response to different management plans.

\section{Conclusion}

Although the threats to the Gulf of Gabes ecosystem are increasing, this study showed that recovery is possible and the decline of several fish stocks can be stopped only if adequate management plans are implemented. The Ecospace model was implemented to explore the potential effects of different MPA designs.

MPAs are promoted as an effective management tool to support the recovery of ecosystems. They have been widely used to protect vulnerable habitats and to conserve marine biodiversity in an ecosystem-based approach. This study suggests that the implementation of a protected area in the Gulf of Gabes could be simultaneously beneficial for the ecosystem and fishing activities. However, the benefits are directly related to the characteristics of the MPA. Our spatial simulations highlight that the location of the protected area is crucial to the success of the MPA. Additionally, an increase in the size of an MPA can result in an increase in the spillover effect and, consequently, in catches in the neighborhood without harming ecosystem integrity. The configuration of the implemented MPA is of capital importance as well. Indeed, a set of many small MPAs was found to be more beneficial than fewer and larger MPAs, especially in terms of catches, because more habitat types can be protected and the emigration of species towards the unprotected areas will be increased. Another outcome of this study was that the intensity of the spillover from the MPA varies according to the habitat types occurring inside and in the adjacent areas of the MPA.

Acknowledgements. This work was partially funded by the "Fondation TOTAL" (project CHARMED). The authors would like to acknowledge the valuable input and financial support of the "Institut de Recherche pour le Développement” (JEAI GAMBAS project).

\section{References}

Aswani S., Hamilton R., 2004, Les aires marines protégées aux Îles Salomon occidentales: faut-il en créer de nombreuses petites ou un petit nombre de grandes. Ressour. Mar. Tradit. Bull. CPS 16, 3-14.

Batisse M., Jeudy de Grissac A., 1998, A global representative system of marine protected areas. Mar. Reg. 3 Mediterr. World Bank Int. Union Conserv. Nat. Nat. Resour. 1, 87.

Ben Abdallah O., Jarboui O., Missaoui H., 2003, Croissance relative, sex-ratio et exploitation de la crevette blanche Metapenaeus monoceros (Fabricius, 1798) du golfe de Gabès (Tunisie).

Ben Meriem S., Gharbi H., Ezzeddine-Najai S., 1994, Le rouget de roche (Mullus surmuletus) en Tunisie: évaluation des stocks et aménagement des pêcheries. Cons. Général Pêch. Pour Méditerranée Consult Techn Eval. Stocks Tunis Tunis. 8-12.

Brahim M., Ben Amor R., Gueddari M., 2003, Essai d'interprétation de la dynamique sédimentaire par l'analyse granulométrique et minéralogique au large du golfe de Gabès.

Browman H.I., Stergiou K.I., 2004, Marine Protected Areas as a central element of ecosystem-based management: defining their location, size and number. Mar. Ecol. Prog. Ser. 274, 271-272.

Chen Z., Xu S., Qiu Y., Lin Z., Jia X., 2009, Modeling the effects of fishery management and marine protected areas on the Beibu Gulf using spatial ecosystem simulation. Fish. Res. 100, 222229. 
Christensen V., Coll M., Steenbeek J., Buszowski J., Chagaris D., Walters C.J., 2014, Representing Variable Habitat Quality in a Spatial Food Web Model. Ecosystems 17, 1397-1412.

Christensen V., Walters C.J., 2004, Ecopath with Ecosim: methods, capabilities and limitations. Ecol. Model. 172, 109-139.

Christensen V., Walters C.J., Pauly D., 2000, Ecopath with Ecosim: a User's Guide. Vanc. CAFisheries Cent. Univ. Br. Columbia 235.

Christensen V., Walters C.J., Pauly D., Forrest R., 2008, Ecopath with Ecosim version 6.User Guide. Lenfest Ocean Futur. Proj. 235.

Christie P., 2004, Marine protected areas as biological successes and social failures in Southeast Asia. In: American Fisheries Society Symposium. pp. 155-164.

Cochrane K., De Young C., 2008, Ecosystem approach to fisheries management in the Mediterranean. UN Food Agric Organ Options Mediterr. Ser. 62, 71-85.

Colléter M., Gascuel D., Albouy C., Francour P., Tito de Morais L., Valls A., Le Loc'h F., 2014, Fishing inside or outside? A case studies analysis of potential spillover effect from marine protected areas, using food web models. J. Mar. Syst. 139, 383-395.

Coll M., Libralato S., 2012, Contributions of food web modelling to the ecosystem approach to marine resource management in the Mediterranean Sea: Ecosystem approach in the Mediterranean Sea. Fish Fish. 13, 60-88.

Coll M., Piroddi C., Steenbeek J., Kaschner K., Ben Rais Lasram F., Aguzzi J., Ballesteros E., Bianchi C.N., Corbera J., Dailianis T., Danovaro R., Estrada M., Froglia C., Galil B.S., Gasol J.M., Gertwagen R., Gil J., Guilhaumon F., Kesner-Reyes K., Kitsos M.-S., Koukouras A., Lampadariou N., Laxamana E., López-Fé de la Cuadra C.M., Lotze H.K., Martin D., Mouillot D., Oro D., Raicevich S., Rius-Barile J., Saiz-Salinas J.I., San Vicente C., Somot S., Templado J., Turon X., Vafidis D., Villanueva R., Voultsiadou E., 2010, The Biodiversity of the Mediterranean Sea: Estimates, Patterns, and Threats. PLoS One 5, e11842.

Dugan J.E., Davis G.E., 1993, Applications of marine refugia to coastal fisheries management. Can. J. Fish. Aquat. Sci. 50, 2029 2042.

Fiorentino F., Ben Meriem S., Bahri T., Camilleri M., Dimech M., Ezzeddine-Naja S., Massa F., Jarbaoui O., Zgozi S., 2008, Synthesis of information on some target species in the MedSudMed Project area (central Mediterranean). MedSudMed Tech. Doc. 15, 67.

Fouzai N., Coll M., Palomera I., Santojanni A., Arneri E., Christensen V., 2012, Fishing management scenarios to rebuild exploited resources and ecosystems of the Northern-Central Adriatic (Mediterranean Sea). J. Mar. Syst. 102-104, 39-51.

Freeman D., MacDiarmid A., Taylor R., 2009, Habitat patches that cross marine reserve boundaries: consequences for the lobster Jasus edwardsii. Mar. Ecol. Prog. Ser. 388, 159-167.

Friedlander A.M., Parrish J.D., 1998, Habitat characteristics affecting fish assemblages on a Hawaiian coral reef. J. Exp. Mar. Biol. Ecol. 224, 1-30.

Gaines S.D., White C., Carr M.H., Palumbi S.R., 2010, Designing marine reserve networks for both conservation and fisheries management. Proc. Natl. Acad. Sci. 107, 18286-18293.

Gell F.R., Roberts C.M., 2003, Benefits beyond boundaries: the fishery effects of marine reserves. Trends Ecol. Evol. 18, 448-455.

Gerber L.R., Botsford L.W., Hastings A., Possingham H.P., Gaines S.D., Palumbi S.R., Andelman S., 2003, Population models for marine reserve design: a retrospective and prospective synthesis. Ecol. Appl. 13, 47-64.

Gharbi H., Ben Meriem S., Bedoui R., El Abed A., 2004, Les pêcheries tunisiennes du rouget de vase (Mullus barbatus Linnaeus, 1758): évaluation des stocks et aménagement des pêcheries. Mar Life 14, 49-57.
Guizien K., Belharet M., Marsaleix P., Guarini J.M., 2012, Using larval dispersal simulations for marine protected area design: Application to the Gulf of Lions (northwest Mediterranean). Limnol. Oceanogr. 57, 1099-1112.

Halouani G., Gascuel D., Hattab T., Lasram F.B.R., Coll M., Tsagarakis K., Piroddi C., Romdhane M.S., Le Loc'h F., 2015, Fishing impact in Mediterranean ecosystems: an EcoTroph modeling approach. J. Mar. Syst. 150, 22-33.

Halouani G., Hattab T., Ben Rais Lasram F., Romdhane M.S., Le Loc'h F., 2013, A trophodynamic approach for the evaluation of Fishery Management Plans in the gulf of Gabes (Southern Tunisia). Rapp Comm Int Mer Médit 40, 756.

Halpern B.S., 2003, The impact of marine reserves: do reserves work and does reserve size matter? Ecol. Appl. 13, 117-137.

Halpern B.S., Walbridge S., Selkoe K.A., Kappel C.V., Micheli F., D’Agrosa C., Bruno J.F., Casey K.S., Ebert C., Fox H.E., Fujita R., Heinemann D., Lenihan H.S., Madin E.M.P., Perry M.T., Selig E.R., Spalding M., Steneck R., Watson R., 2008, A Global Map of Human Impact on Marine Ecosystems. Science 319, 948 952.

Harrison H.B., Williamson D.H., Evans R.D., Almany G.R., Thorrold S.R., Russ G.R., Feldheim K.A., van Herwerden L., Planes S., Srinivasan M., Berumen M.L., Jones G.P., 2012, Larval Export from Marine Reserves and the Recruitment Benefit for Fish and Fisheries. Curr. Biol. 22, 1023-1028.

Hastings A., Botsford L.W., 2003, Comparing designs of marine reserves for fisheries and for biodiversity. Ecol. Appl. 13, 65-70.

Hattab T., Ben Rais Lasram F., Albouy C., Romdhane M.S., Jarboui O., Halouani G., Cury P., Le Loc'h F., 2013a, An ecosystem model of an exploited southern Mediterranean shelf region (Gulf of Gabes, Tunisia) and a comparison with other Mediterranean ecosystem model properties. J. Mar. Syst. 128, 159-174.

Hattab T., Ben Rais Lasram F., Albouy C., Sammari C., Romdhane M.S., Cury P., Leprieur F., Le Loc'h F., 2013b, The Use of a Predictive Habitat Model and a Fuzzy Logic Approach for Marine Management and Planning. PLoS ONE 8, e76430.

Hattour A., 1991, Le chalutage dans les eaux Tunisiennes réalités et considérations législatives particulièrement dans les Golfe de Tunis et de Gabès. Note Inst. Natl. Sci. Tech. Océan. Pêche Salammbô 13.

Hilborn R., Micheli F., De Leo G.A., 2006, Integrating marine protected areas with catch regulation. Can. J. Fish. Aquat. Sci. 63, 642-649.

Hilborn R., Stokes K., Maguire J.-J., Smith T., Botsford L.W., Mangel M., Orensanz J., Parma A., Rice J., Bell J., Cochrane K.L., Garcia S., Hall S.J., Kirkwood G.., Sainsbury K., Stefansson G., Walters C., 2004, When can marine reserves improve fisheries management? Ocean Coast. Manag. 47, 197-205.

Jabeur C., Gobert B., Missaoui H., 2000, Typologie de la flottille de pêche côtière dans le golfe de Gabès (Tunisie). Aquat. Living Resour. 13, 421-428.

Jackson J.B., Kirby M.X., Berger W.H., Bjorndal K.A., Botsford L.W., Bourque B.J., Bradbury R.H., Cooke R., Erlandson J., Estes J.A., others, 2001, Historical overfishing and the recent collapse of coastal ecosystems. Science 293, 629-637.

Jarboui O., Ghorbel M., Bouaïn A., 1998, Le stock du pageot (Pagellus erythrinus) dans le golfe de Gabès (Tunisie): etat d'exploitation et possibilités d'aménagement. Cah. Options Méditerranéennes 35, 251-260.

Jennings S., Kaiser M.J., 1998, The Effects of Fishing on Marine Ecosystems. In: Advances in Marine Biology. Elsevier, pp. 201352. 
Kaiser M.J., de Groot S.J., 2000, Effects of fishing on non-target species and habitats. Blackwell Science.

Le Quesne W.J.F., Arreguín-Sánchez F., Albañez-Lucero M., Cheng H., Cruz-Escalona V., Daskalov G., Ding H., GonzálezRodríguez E., Heymans J.J., Jiang H., others, 2007, Analysis of the ecosystem effects of selected MPAs using Ecospace spatial ecosystem models. INCOFISH.

Lotze H.K., Lenihan H.S., Bourque B.J., Bradbury R.H., Cooke R.G., Kay M.C., Kidwell S.M., Kirby M.X., Peterson C.H., Jackson J.B., 2006, Depletion, degradation, and recovery potential of estuaries and coastal seas. Science 312, 1806-1809.

Lubchenco J., Palumbi S.R., Gaines S.D., Andelman S., 2003, Plugging a hole in the ocean: the emerging science of marine reserves. Ecol. Appl. 13, 3-7.

Martell S.J.D., Essington T.E., Lessard B., Kitchell J.F., Walters C.J., Boggs C.H., 2005, Interactions of productivity, predation risk, and fishing effort in the efficacy of marine protected areas for the central Pacific. Can. J. Fish. Aquat. Sci. 62, 1320-1336.

Missaoui H., Jabeur C., Gobert R., Jarboui O., El Abed A., 2000, Analyse typologique de la flottille chalutière du golfe de Gabès, Sud-Est de Tunisie.

Murray S.N., Ambrose R.F., Bohnsack J.A., Botsford L.W., Carr M.H., Davis G.E., Dayton P.K., Gotshall D., Gunderson D.R., Hixon M.A., others, 1999, No-take reserve networks: sustaining fishery populations and marine ecosystems. Fisheries 24, 11-25.

Natale S., Sorgente R., Ribotti A., Olita A., others, 2006, Central Mediterranean Sea forecast: effects of high-resolution atmospheric forcings. Ocean Sci. Discuss. 3, 637-669.

Papaconstantinou C., Farrugio H., 2000, Fisheries in the Mediterranean. Mediterr. Mar. Sci. 1, 5-18.

Pauly D., Christensen V., Guénette S., Pitcher T.J., Sumaila U.R., Walters C.J., Watson R., Zeller D., 2002, Towards sustainability in world fisheries. Nature 418, 689-695.

Pinnegar J., McClanahan T., Fernandes L., Boncoeur J., Fanshawe S., 2004, Predation in marine reserves: how increases in predator populations can impact diversity and fisheries goals. MPA News $6,1-3$.

Pitcher T.J., Cheung W.W.L., 2013, Fisheries: Hope or despair? Mar Pollut. Bull. 74, 506-516.

Razon B.C., Liao L.M., Nakagoshi N., 2012, Success and failure of marine protected area management affecting the fish catch by adjacent fishermen in Sarangani Bay, Mindanao, Philippines. S. Pac. Stud. 33, 1-23.
Roberts C.M., Andelman S., Branch G., Bustamante R.H., Carlos Castilla J., Dugan J., Halpern B.S., Lafferty K.D., Leslie H., Lubchenco J., others, 2003, Ecological criteria for evaluating candidate sites for marine reserves. Ecol. Appl. 13, 199-214.

Romagnoni G., Mackinson S., Hong J., Eikeset A.M., 2015, The Ecospace model applied to the North Sea: Evaluating spatial predictions with fish biomass and fishing effort data. Ecol. Model. $300,50-60$

Rossetto M., Micheli F., Saenz-Arroyo A., Montes J.A.E., De Leo G.A., Rochet M.-J., 2015, No-take marine reserves can enhance population persistence and support the fishery of abalone. Can. J. Fish. Aquat. Sci. 72, 1503-1517.

Saïdi B., Bradaï M.N., Bouaïumln A., Guélorget O., Capapé C., 2005 , The reproductive biology of the sandbar shark, Carcharhinus plumbeus (Chondrichthyes: Carcharhinidae), from the Gulf of Gabès (southern Tunisia, central Mediterranean). Acta Adriat. 46, 47-62.

Saïdi B., Bradaï M.N., Bouaïn A., 2008, Reproductive biology of the smooth-hound shark Mustelus mustelus (L.) in the Gulf of Gabès (south-central Mediterranean Sea). J. Fish Biol. 72, 1343-1354.

Salomon A.K., Waller N.P., McIlhagga C., Yung R.L., Walters C., 2002, Modeling the trophic effects of marine protected area zoning policies: a case study. Aquat. Ecol. 36, 85-95.

Sammari C., Koutitonsky V.G., Moussa M., 2006, Sea level variability and tidal resonance in the Gulf of Gabes, Tunisia. Cont. Shelf Res. 26, 338-350.

Tupper M.H., 2007, Spillover of commercially valuable reef fishes from marine protected areas in Guam, Micronesia. Fish. Bull. $105,527-537$.

Walters C., Christensen V., Pauly D., 1997, Structuring dynamic models of exploited ecosystems from trophic mass-balance assessments. Rev. Fish Biol. Fish. 7, 139-172.

Walters C., Pauly D., Christensen V., 1999, Ecospace: prediction of mesoscale spatial patterns in trophic relationships of exploited ecosystems, with emphasis on the impacts of marine protected areas. Ecosystems 2, 539-554.

Ward T.J., Heinemann D., Evans N., 2001, The role of marine reserves as fisheries management tools. Rev. Concepts Evid. Int. Exp. Bur. Rural Sci. Canberra.

Worm B., Barbier E.B., Beaumont N., Duffy J.E., Folke C., Halpern B.S., Jackson J.B., Lotze H.K., Micheli F., Palumbi S.R., others, 2006, Impacts of biodiversity loss on ocean ecosystem services. Science 314, 787-790. 
Annex 1. Parameters of the Ecopath model for the Gulf of Gabes ecosystem.

\begin{tabular}{|c|c|c|c|c|c|c|}
\hline Group name & $\begin{array}{c}\text { Trophic } \\
\text { level }\end{array}$ & $\begin{array}{c}\text { Biomass } \\
\left(\mathrm{t} / \mathrm{km}^{2}\right)\end{array}$ & $\begin{array}{c}\text { Production/ } \\
\text { biomass (/year) }\end{array}$ & $\begin{array}{l}\text { Consumption/ } \\
\text { biomass (/year) }\end{array}$ & $\begin{array}{l}\text { Ecotrophic } \\
\text { efficiency }\end{array}$ & $\begin{array}{l}\text { Production/ } \\
\text { consumption }\end{array}$ \\
\hline Phytoplankton & 1.000 & 7.650 & 160.000 & 0.000 & 0.309 & \\
\hline Macro-algae & 1.000 & 2.188 & 13.400 & 0.000 & 0.950 & \\
\hline Posidonia oceanica & 1.000 & 0.046 & 15.033 & 0.000 & 0.950 & \\
\hline Micro- and mesozooplankton & 2.105 & 8.460 & 32.395 & 51.069 & 0.950 & 0.634 \\
\hline Macrozooplankton & 3.093 & 3.463 & 22.650 & 56.570 & 0.950 & 0.400 \\
\hline Foraminifera & 2.000 & 0.368 & 7.844 & 23.532 & 0.950 & 0.333 \\
\hline Invertebrate suspension feeders & 2.725 & 7.382 & 1.647 & 9.904 & 0.950 & 0.166 \\
\hline Polychaetes & 2.361 & 4.416 & 3.502 & 19.723 & 0.950 & 0.178 \\
\hline Amphipoda and Isopoda & 2.000 & 5.464 & 2.405 & 26.199 & 0.950 & 0.092 \\
\hline Echinoderms & 2.327 & 4.526 & 0.570 & 2.460 & 0.950 & 0.232 \\
\hline Benthic molluscs & 2.353 & 4.258 & 1.886 & 9.386 & 0.950 & 0.201 \\
\hline Crabs & 3.211 & 2.089 & 2.555 & 4.953 & 0.950 & 0.516 \\
\hline Benthic cephalopods & 3.701 & 0.552 & 2.800 & 5.642 & 0.968 & 0.496 \\
\hline Benthopelagic cephalopods & 4.225 & 0.065 & 2.712 & 31.640 & 0.885 & 0.086 \\
\hline Mantis shrimp & 3.716 & 0.560 & 1.590 & 4.854 & 0.884 & 0.328 \\
\hline Caramote prawn & 3.279 & 0.131 & 2.260 & 7.665 & 0.994 & 0.295 \\
\hline Alien shrimps & 2.868 & 0.125 & 3.800 & 7.665 & 0.996 & 0.496 \\
\hline Deep shrimps & 3.270 & 0.036 & 2.796 & 7.665 & 0.952 & 0.365 \\
\hline Horse mackerel & 3.663 & 1.550 & 0.716 & 9.044 & 0.997 & 0.079 \\
\hline European pilchard & 3.122 & 3.829 & 1.116 & 11.403 & 0.927 & 0.098 \\
\hline Round sardinella & 3.125 & 1.850 & 0.853 & 9.635 & 0.953 & 0.089 \\
\hline European anchovy & 3.081 & 0.700 & 1.089 & 10.505 & 0.882 & 0.104 \\
\hline Picarel & 3.104 & 0.618 & 0.882 & 27.280 & 0.791 & 0.032 \\
\hline Bogue & 3.200 & 0.538 & 0.772 & 19.813 & 0.782 & 0.039 \\
\hline Benthic invertebrate feeders (1) & 3.537 & 0.210 & 0.608 & 6.834 & 0.997 & 0.089 \\
\hline Benthic invertebrate feeders (2) & 3.391 & 0.049 & 0.723 & 8.529 & 0.946 & 0.085 \\
\hline Mullets & 3.305 & 0.085 & 1.310 & 6.587 & 0.990 & 0.199 \\
\hline Piscivorous Fish & 4.213 & 0.067 & 0.359 & 4.335 & 0.788 & 0.083 \\
\hline Sparidae & 3.313 & 0.216 & 0.779 & 7.832 & 0.959 & 0.099 \\
\hline Macro-carnivorous Fish (1) & 4.026 & 0.189 & 0.639 & 9.380 & 0.999 & 0.068 \\
\hline Macro-carnivorous Fish (2) & 4.056 & 0.052 & 0.571 & 8.529 & 0.949 & 0.067 \\
\hline Rays (1) & 4.060 & 0.363 & 0.239 & 3.277 & 0.095 & 0.073 \\
\hline Rays (2) & 3.780 & 0.133 & 0.342 & 3.736 & 0.267 & 0.092 \\
\hline Sharks & 4.355 & 0.193 & 0.544 & 4.233 & 0.220 & 0.128 \\
\hline Small tuna & 4.419 & 0.074 & 0.591 & 8.193 & 0.950 & 0.072 \\
\hline Medium pelagic fish & 4.118 & 1.462 & 0.111 & 1.306 & 0.891 & 0.085 \\
\hline Atlantic bluefin tuna & 4.381 & 0.230 & 0.313 & 3.513 & 0.899 & 0.089 \\
\hline Dolphins & 4.339 & 0.080 & 0.075 & 14.361 & 0.000 & 0.005 \\
\hline Sea birds & 3.772 & 0.002 & 0.200 & 62.751 & 0.000 & 0.003 \\
\hline Discards & 1.000 & 0.381 & & & 0.447 & \\
\hline Detritus & 1.000 & 30.000 & & & 0.280 & \\
\hline
\end{tabular}



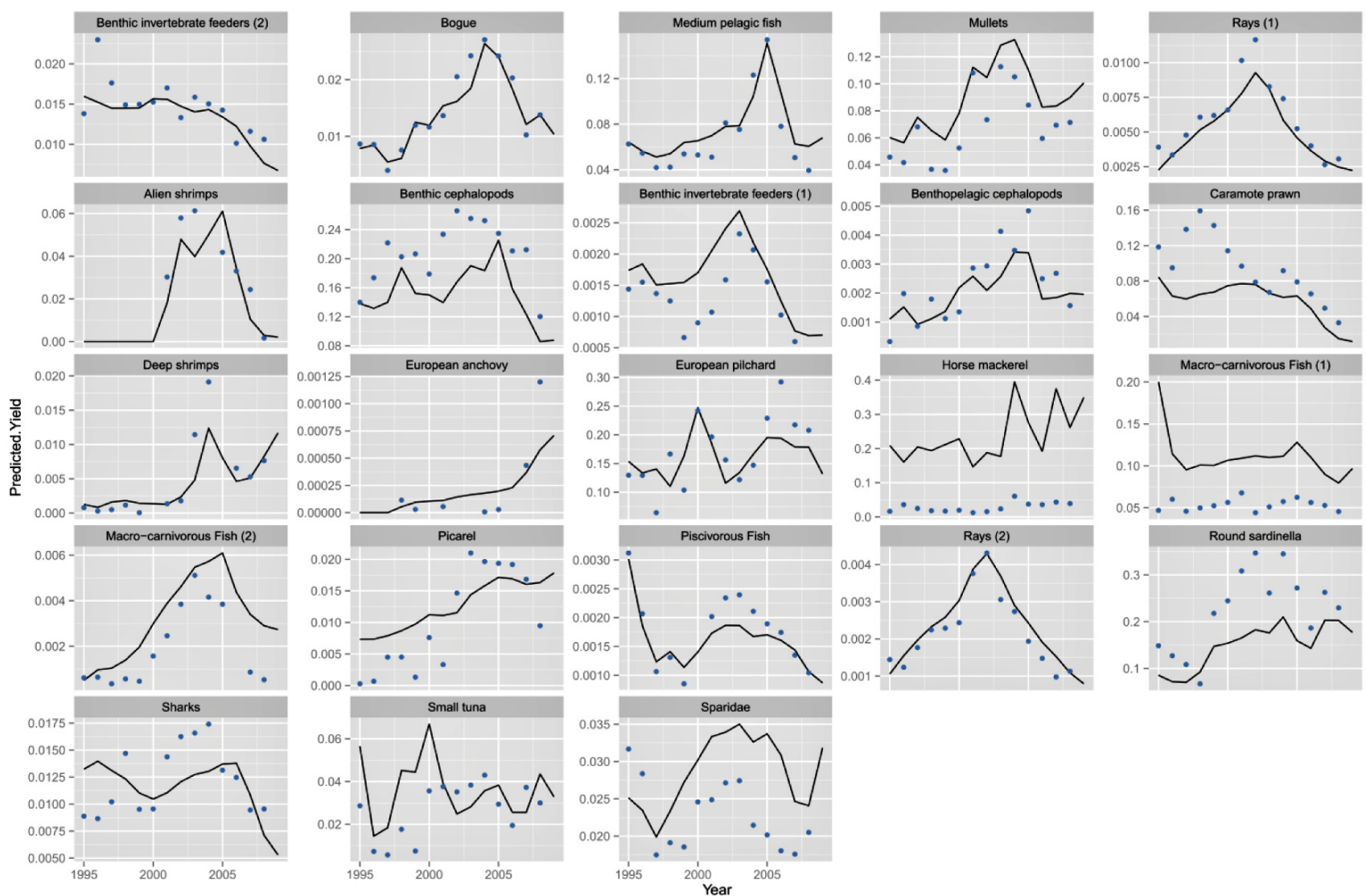

Annex 2. Comparison between time series of landings (points) and model outputs (lines) for the period 1995-2008. 
Annex 3. Input parameters used in the Gulf of Gabes Ecospace model for each functional group.

\begin{tabular}{|c|c|c|c|c|c|}
\hline Functional group & $\begin{array}{c}\text { Trophic } \\
\text { level }\end{array}$ & $\begin{array}{c}\text { Baseline } \\
\text { dispersal rate } \\
(\mathrm{km} / \text { year })\end{array}$ & $\begin{array}{c}\text { Relative dispersal } \\
\text { rate in unsuitable } \\
\text { habitat }\end{array}$ & $\begin{array}{c}\text { Relative vulnerability } \\
\text { to predation in } \\
\text { unsuitable habitat }\end{array}$ & $\begin{array}{c}\text { Relative feeding } \\
\text { rate in unsuitable } \\
\text { habitat }\end{array}$ \\
\hline Phytoplankton & 1.00 & 3 & 1 & 2 & 0.95 \\
\hline Macro-algae & 1.00 & 3 & 1 & 2 & 0.95 \\
\hline Posidonia oceanic & 1.00 & 3 & 1 & 2 & 0.95 \\
\hline Micro- and mesozooplankton & 2.10 & 3 & 1 & 2 & 0.01 \\
\hline Macrozooplankton & 3.09 & 3 & 1 & 2 & 0.01 \\
\hline Foraminifera & 2.00 & 3 & 1 & 2 & 0.01 \\
\hline Invertebrate suspension feeders & 2.72 & 3 & 1 & 2 & 0.01 \\
\hline Polychaetes & 2.36 & 3 & 1 & 2 & 0.01 \\
\hline Amphipoda and Isopoda & 2.00 & 3 & 1 & 2 & 0.01 \\
\hline Echinoderms & 2.32 & 3 & 1 & 2 & 0.01 \\
\hline Benthic mollusks & 2.35 & 3 & 2 & 2 & 0.01 \\
\hline Crabs & 3.21 & 3 & 2 & 2 & 0.01 \\
\hline Benthic cephalopods & 3.70 & 3 & 2 & 2 & 0.30 \\
\hline Benthopelagic cephalopods & 4.22 & 3 & 2 & 2 & 0.60 \\
\hline Mantis shrimp & 3.71 & 30 & 2 & 2 & 0.30 \\
\hline Caramote prawn & 3.27 & 30 & 2 & 2 & 0.01 \\
\hline Alien shrimps & 2.86 & 30 & 2 & 2 & 0.01 \\
\hline Deep shrimps & 3.27 & 30 & 2 & 2 & 0.01 \\
\hline Horse mackerel & 3.71 & 300 & 3 & 2 & 0.30 \\
\hline European pilchard & 3.12 & 300 & 3 & 2 & 0.01 \\
\hline Round sardinella & 3.12 & 300 & 3 & 2 & 0.01 \\
\hline European anchovy & 3.08 & 300 & 3 & 2 & 0.01 \\
\hline Picarel & 3.10 & 300 & 3 & 2 & 0.01 \\
\hline Bogue & 3.20 & 300 & 3 & 2 & 0.01 \\
\hline Benthic invertebrate feeders (1) & 3.53 & 300 & 3 & 2 & 0.30 \\
\hline Benthic invertebrate feeders (2) & 3.39 & 300 & 3 & 2 & 0.01 \\
\hline Mullets & 3.30 & 300 & 2 & 2 & 0.01 \\
\hline Piscivorous Fish & 4.21 & 300 & 3 & 2 & 0.60 \\
\hline Sparidae & 3.35 & 300 & 4 & 2 & 0.01 \\
\hline Macro-carnivorous Fish (1) & 4.02 & 300 & 4 & 2 & 0.60 \\
\hline Macro-carnivorous Fish (2) & 4.05 & 300 & 4 & 2 & 0.60 \\
\hline Rays (1) & 4.06 & 30 & 4 & 2 & 0.60 \\
\hline Rays (2) & 3.78 & 30 & 4 & 2 & 0.30 \\
\hline Sharks & 4.35 & 300 & 5 & 2 & 0.60 \\
\hline Small tuna & 4.45 & 300 & 5 & 2 & 0.60 \\
\hline Medium pelagic fish & 4.12 & 300 & 5 & 2 & 0.60 \\
\hline Atlantic bluefin tuna & 4.43 & 300 & 5 & 2 & 0.60 \\
\hline Dolphins & 4.34 & 300 & 5 & 2 & 0.60 \\
\hline Sea birds & 3.77 & 300 & 5 & 2 & 0.30 \\
\hline
\end{tabular}

